\title{
EL CUERPO EN LA MEMORIA CULTURAL KAWÉSQAR
}

ÁNGEL ACUÑA D. a, b

\section{RESUMEN}

El objetivo central de este trabajo centra la atención en el estudio de diversos aspectos de la sociedad y la cultura kawésqar a través de los hechos históricos y etnográficos que se derivan de su corporeidad. Con esa doble perspectiva metodológica y la limitación que imponen los datos producidos en el proceso de investigación, ilustramos el papel que han desempeñado distintas contingencias corporales (parto, primeros cuidados, rituales de iniciación, vestuario, alimentación, prácticas de higiene, salud, sexualidad, juegos, danzas, gestualidad, etc.) en la cultura de los antiguos kawésqar, observando así mismo en qué medida han sido alteradas por los distintos agentes que han intervenido en el proceso de cambio (navegantes, misioneros, colonos, política estatal, etc.) hasta la época contemporánea.

PALABRAS CLAVE: Kawésqar, cuerpo, memoria, cultura.

\section{THE BODY IN THE CULTURAL MEMORY KAWÉSQAR}

\begin{abstract}
The main objective of this work focuses on the study of various aspects of kawesqar society and culture through historical and ethnographic facts derived from their corporality. With this dual methodological perspective and the limits imposed by the data produced in the research process, we show the role played by the different physical contingencies (childbirth, primary care, initiation rituals, clothes, nutrition, hygienic practices, health, sexuality, games, dances, gestures, ...) in Kawesqar ancient culture, noting likewise the extent of the alteration caused by the different facts that have been involved in the change process (sailors, missionaries, settlers, government policy, ...) until the present.
\end{abstract}

KEY WORDS: Kawésqar, body, memory, culture.

a Universidad Autónoma de Chile. Facultad de Ciencias Sociales y Humanidades. Av. Pedro de Valdivia 425. Providencia. Santiago de Chile. Chile. acuna@ugr.es

b Universidad de Granada. Departamento de Antropología Social, Facultad de Filosofía y Letras, Campus de Cartuja, s/n. 18071 Granada. España. 


\section{INTRODUCCIÓN}

El cuerpo humano constituye en la actualidad uno de los principales medios para entender las relaciones sociales y la producción cultural en poblaciones concretas. Como vehículo de ser en el mundo, ocupa un papel esencial en el diseño de la realidad y constituye el parámetro de todo complejo cultural. Como decía MerleauPonty (1966) el mundo es percibido desde una determinada posición corporal en el tiempo y en el espacio, dependiendo la propia existencia de la manera en que encarnamos la experiencia que vivimos. Mauss lo observó como "el primero y más natural instrumento del hombre" (1979 [1936], p. 352$)^{1}$ y puso de relieve las distintas "maneras que los hombres en cada sociedad, de un modo tradicional, saben servirse de su cuerpo" (Ibid.: 345). Desde entonces, son ya muchos los autores que, desde un punto de vista sociocultural, han considerado el estudio del cuerpo como una cuestión central en la teoría social contemporánea, en cuanto que constituye un sistema de comunicación, un medio de lenguaje, productor de significados diversos (Birdwistell, 1952; Hall, 1972; Goffman, 1987; Le Breton, 1991), así como un objeto o signo de consumo (Baudrillard, 1974; Bourdieu, 1991; Godelier, 1986; Csordas, 2003 [1994]), y un instrumento de poder (Brohm 1982; Foucault 1984; Durán, 1988; Le Goff, 1990; Entwistle, 2002; Esteban, 2004). De todo ello queda patente el carácter social y cultural del cuerpo humano, que además de sentido práctico tiene valor simbólico, cuerpo en movimiento que, junto con su envoltura, es capaz de reflejar y aún generar distintos aspectos ecológicos, económicos, sociales, políticos, ideológicos e interétnicos del entramado cultural en donde se halla inscrito, acreditándose así como

1 El estudio sobre las técnicas y movimientos corporales fue publicado originalmente en el Journal de Psychologie, XXXII, números 3-4, 1936. Conferencia dada en mayo de 1934 en la Sociedad de Psicología.

2 Según consta en la base de datos de la CONADI (Corporación Nacional para el Desarrollo Indígena) para 2008, 343 personas fueron reconocidas como kawésqar (171 varones y 172 mujeres). Sin embargo, en enero de 2009 revisamos detenidamente dicho censo con la ayuda de un grupo de cinco kawésqar residentes en Punta Arenas, y la cifra quedó reducida a 225 personas más 32 de dudosa procedencia (dicha reducción se produjo con motivo de un importante aliado para comprender y explicar la diversidad del comportamiento humano.

Al hilo de lo dicho, el objetivo central de este trabajo centra la atención en el estudio de un modelo de sociedad amerindia, en otro tiempo más extendida, con una estrategia adaptativa propia de tierras frías de litoral marítimo, a través de los datos históricos y etnográficos que se derivan de su corporeidad. Los escasos descendientes del pueblo kawéskar ubicados en Puerto Edén, Puerto Natales y Punta Arenas ${ }^{2}$, por el reducido número de personas integrantes del grupo, la definida circunscripción territorial y adaptación ecológica, y el acelerado proceso de cambio cultural experimentado en los últimos 50 años, constituye un caso ideal para pensar el cuerpo desde la perspectiva de la tradición y el cambio social, para observar a través de un estudio de caso étnico qué técnicas corporales han perdurado, desaparecido o transformado, de acuerdo al sentido pragmático y/o simbólico que poseían o aún poseen en la actualidad.

Esta investigación fue llevada a cabo entre 2008 y 2010. Durante sus tres años de desarrollo tuvimos ocasión de realizar trabajo de campo etnográfico en Puerto Edén y Punta Arenas en tres estancias sucesivas que sumaron un total de 11 meses, aunque, debido al elevado grado de cambio social y cultural de la población kawésqar, los datos registrados a través de la observación sistemática y las entrevistas e historias de vida, no fueron lo suficientemente consistentes para ilustrar el modo de vida más próximo a la tradición de las generaciones pasadas, y optamos por emplear el material histórico encontrado en las fuentes documentales como principal base de datos para hacer memoria de la cultura a través del cuerpo.

Con una doble metodología por tanto,

aparecer en la base de datos un buen número de personas ya fallecidas, así como cónyuges de kawéskar que no eran originarios de esa etnia, según la opinión ofrecida y contrastada por los cinco integrantes del grupo kawésqar que examinó el listado). En cuanto a Puerto Edén, el censo registrado personalmente en enero de 2009 fue de 20 kawésqar (9 varones y 11 mujeres). A los residentes en Puerto Edén se les consideran "kawésqar autóctonos" y a los de Punta Arenas y Puerto Natales "kawésqar urbanos". La evolución demográfica kawésqar desde principios del siglo XIX hasta 1995, según diversas fuentes, se puede ver en Martinic (2004, pp. 66-68). 
esencialmente histórica, y etnográfica de manera complementaria, trataremos de ilustrar aquí el papel que han desempeñado distintas contingencias corporales (parto, prácticas de higiene, vestuario, alimentación, sexualidad, juegos, danzas, etc.) en la cultura de los antiguos kawésqar, observando así mismo en qué medida han sido alteradas por los distintos agentes que han intervenido en el proceso de cambio (navegantes, misioneros, colonos, política estatal, etc.) hasta la época contemporánea.

Aunque en el inicial proyecto de investigación las preguntas fundamentales fueron muchas y variadas, concluido el proceso y a la vista de los datos producidos, la principal pregunta a la que aquí damos respuesta es a: ¿De qué manera se caracterizan contingencias corporales tales como las prácticas del nacimiento y el desarrollo en la infancia, los rituales de iniciación, las formas de vestir y ornamentarse, la alimentación, los cuidados higiénicos y sanitarios, la sexualidad, las actividades lúdicas y expresivas, y la motricidad cotidiana? De modo complementario, en razón a la cantidad y calidad de datos históricos registrados y al material etnográfico producido, con menor densidad de respuesta abordaremos también otras, tales como: ¿Existen conductas corporales apreciadas como señas de identidad? ¿Qué diferencias se observan en razón al género y a la edad? ¿Qué correspondencias existen entre las contingencias corporales antes citadas y el sentido pragmático de la vida, las relaciones sociales, la estructura de autoridad, la cosmovisión, o los procesos de aculturación? ¿Qué tipo de influencias foráneas recibidas han conducido a cambios culturales en relación con la corporeidad?

El esquema que seguiremos a continuación intentará responder por tanto a todas estas interrogantes, con la limitación que impongan los datos ${ }^{3}$, ordenando el contenido en unidades de análisis y éstas en tres grandes apartados: 1. Características antropométricas, nacimiento, desarrollo en la infancia y rituales de iniciación. 2. Vestuario y ornamentos, alimentación, higiene y salud, y sexualidad. 3. Actividades lúdicas,

3 En relación con la búsqueda bibliográfica relativa a la población kawésqar, cabe decir que se encuentra muy dispersa y escasean los trabajos realmente etnográficos; por ello, a excepción de las observaciones y testimonios de informantes aportados de primera mano como fruto del expresivas y motricidad cotidiana. Para terminar con unas reflexiones finales.

\section{CARACTERÍSTICAS ANTROPOMÉTRICAS, NACIMIENTO, DESARROLLO EN LA INFANCIA Y RITUALES DE INICIACIÓN}

De acuerdo a los abundantes datos registrados por Gusinde (1989 [1939], pp. 124-335) en la península Muñoz Gamero y por Emperaire (1963, pp. 96-104) en el entorno de Puerto Edén, así como, de manera más parcial, a los ofrecidos por Lautaro Navarro (1894) (cfr. Vega \& Grendi, 2002, p. 38), de Agostini (1941, pp. 46), Kuzmanich (1980, pp. 89-91) o Lalueza et al. (1997, pp. 46-54), en relación con las características antropométricas de la población kawésqar, podemos afirmar que, en general, comparten los siguientes rasgos: cuerpos robustos y macizos, talla media en torno al 1.58 m. el hombre y $1.46 \mathrm{~m}$. la mujer, tronco y brazos musculosos, fuertes, muy desarrollados en relación con las piernas que son comparativamente más delgadas y cortas, cubiertos por una densa capa de tejido adiposo, piel pálida color marrón o amarillo pardo oscuro, cabello abundante, grueso, negro y liso, escasa vellosidad, cabeza proporcional a su talla (cráneo mesocéfalo) o algo más grande, rostro plano y alargado, frente estrecha, pómulos pronunciados, boca grande que se mantiene normalmente algo abierta, labios semigruesos, ojos oscuros y ligeramente oblicuos, y nariz alta y estrecha. Rasgos que en definitiva se encuentran adaptados al ambiente húmedo y frio de los canales patagónicos y al estilo de vida canoero y nómada que les caracteriza.

En orden cronológico al crecimiento y desarrollo humano, las técnicas del cuerpo relacionadas con el nacimiento estuvieron sujetas al aislamiento, la incertidumbre y dureza que impone el ambiente físico y la costumbre social. En tal sentido, la mujer desempeñó durante todo el embarazo las tareas cotidianas sin mayores cuidados hasta el último momento. Nada parecido por tanto a la situación que

propio trabajo de campo, y del que personalmente me responsabilizo, los datos atribuidos a los distintos autores aquí citados (entre los que sobresalen Gusinde y Emperaire) son de la responsabilidad de cada cual en cuestión de validez y fiabilidad. 
se vive actualmente en Puerto Edén, y no digamos ya en Punta Arenas, en donde el control prenatal está asegurado, así como la evacuación en caso de dificultades y la asistencia al parto en un hospital. El parto en el pasado, aunque se procuraba que fuera en el interior de la choza y que estuviera acompañado de alguna mujer, pariente o vecina eventual, no siempre era así y la posibilidad de tenerlo en la misma canoa durante una travesía o incluso en soledad, empujando el vientre en posición de cuclillas, era una posibilidad harto frecuente. El marido, no obstante, o cualquier otro hombre, parece que salvo fuerza mayor, se mantenía al margen, ocupado en cortar y acarrear leña, agua, o buscar alimentos.

Parto sujeto a enorme riesgo para la criatura y la madre al no estar muchas veces asegurada la atención competente o al menos la simple compañía, ni saber las dificultades sobrevenidas en el propio alumbramiento. Sin conocer la casuística en mortalidad de recién nacidos, tal vez la escasa media de hijos por familia que refiere Lautaro Navarro (cfr. Vega \& Grendi, 2002, p. 39) en 1894 (dos, tres o a lo sumo cuatro hijos por familia), se pueda deber a una alta tasa de mortalidad infantil durante el parto o en los primeros años de vida.

Pasado el trance, los testimonios históricos coinciden en afirmar que la mujer iba a lavarse a la orilla de la playa con la fría agua de mar, mientras que el primer baño de la criatura, indica Gusinde (1951, p. 252), se lo daba la madre u otra persona encargada de tal función, rociándole el cuerpo con varios buches de agua tibia que mantenían en la boca por unos minutos para calentarla.

El recién nacido recibe el primer lavado de la forma siguiente: la india coge al niño con sus dos manos por debajo de los brazos y se lo coloca sobre sus muslos; varias veces consecutivas se llena la boca de agua, la retiene algunos minutos para que se caliente y la rocía después al niño, como si fuera una ducha de muchos agujeros. De esta forma le moja todo el cuerpo y lo seca después con un blanco manojo de musgos o con unas finísimas virutitas de madera. Con el mayor cuidado le limpia los ojos, las orejas, la boca y la nariz, después lo acuesta encima del lado peludo de una blanda piel, previamente buscada; la mayoría de las veces de zorro o de nutria, sobre la cual se ha esparcido antes una espesa capa de plumas. (Ibid.: 252).

Al día siguiente la madre volverá a bañarse en el mar pero esta vez en compañía de su bebé.

Apenas el recién nacido ha visto la luz del mundo, es frotado con bolas de musgo húmedo y luego lavado con agua de mar fría, la cual la misma madre recoge de una vasija de corteza que está junto a ella, o desde la canoa o de la playa directamente. [...] Después de secarlo, la madre lo envuelve, para que se caliente pronto, en las pieles de nutria, de tal manera que los pelos suaves quedan hacia adentro, esto es, tocando la piel del bebé. (Gusinde, 1991 [1974], pp. 363-364).

Lautaro Navarro (cfr. Vega \& Grendi, 2002, p. 39) también coincide en afirmar que la mujer tras dar a luz se bañaba en el mar, pero sobre el aseo del recién nacido indica que era bañado no con agua sino en cieno o barro, repitiéndose ese tipo de baño varias veces durante el primer año.

Gabriela Paterito, como mujer kawésqar actualmente viva y con 8 hijos (tres de ellos ya fallecidos), dice a este respecto que antes todo era más natural, que el parto, según su experiencia, no era tan sufrido, ni para las mujeres ni para los "guaguas", que las mujeres tenían más capacidad de aguante que ahora, pero se extraña de que se lavaran a los recién nacidos en la gélida agua de mar; aunque deja abierta esa posibilidad al reconocer que la vida de sus antepasados fue bastante más dura que la que ella experimentó, y que no conoce las costumbres de los demás grupos situados más al sur.

Sea como sea, aparte del lavado e higiene posterior del bebé, al que Gusinde (1991 [1974], p. 368) dice que se prestaba poca atención, mantener seco su cuerpo y administrarle calor con el contacto corporal y la cobertura de pieles de foca, lobo marino o huemul (con el pelo en contacto con la piel) era imprescindible para la supervivencia en un ambiente húmedo y frío, a lo que se unía el confort que supone acostarse sobre un mullido lecho de plumas bajo una piel.

La placenta se hacía desaparecer bajo tierra 
en lugar oculto, no sabemos exactamente por qué, aunque parece ser que se trataba de evitar que sirviera de comida para los animales. Y sobre el cordón umbilical una vez seco y desprendido de la criatura, lo conservaba el padre atado a su cuello, y a veces la madre, si era niña, durante al menos un año, según Gusinde (1991 [1974], pp. 365-366) como expresión pública del estado de paternidad o maternidad y para evitar que su hijo o hija enferme. Las prohibiciones y prescripciones del padre en relación con la comida antes de que se desprenda el cordón del bebé, la prohibición o no recomendación de realizar grandes travesías por mar en las seis semanas siguientes (Gusinde, 1991 [1974], pp. 253), o el hecho de que el padre se tuviera que acostar separado de la madre durante los 15 días siguientes al parto y evitar las relaciones sexuales (Cárdenas et al. 1993, p. 79), son todas ellas situaciones sobrevenidas con motivo del nacimiento de un nuevo ser, sin que podamos establecer con claridad los sentidos que evoca.

Llama la atención también la referencia a la covada que encontramos en la literatura acerca de los yagán o yámana (Gusinde, 1951, p. 253), grupo muy próximo a los kawésqar (aunque diferentes), con esa inversión de la norma en donde el marido permanecía en cama con el recién nacido durante algunos días, mientras la mujer ejercía otras tareas; práctica que en cualquier caso no fue reconocida por los actuales kawésqar en su pueblo.

El periodo de lactancia se prolongaba al menos hasta que al bebé le salían los primeros dientes y podía empezar a masticar el alimento semisólido que la mamá le daba previamente masticado por ella, o incluso se podía prolongar por tres o cuatro años hasta que tuviera un nuevo bebé (Cárdenas et al. 1993, p. 80; Lautaro Navarro, cfr. Vega \& Grendi, 2002, p. 39), utilizándose para el destete un trozo de grasa de guanaco ${ }^{4} \mathrm{O}$ tocino de foca calentado previamente (Gusinde, 1951, p. 256). El hecho de amamantar por algún tiempo al hijo de otra mujer por la falta de leche de la madre o cualquier otra circunstancia no era tampoco de extrañar.

Es la madre quien estaba permanentemente en contacto con el bebé hasta el año de vida que comenzara a caminar, trasportándolo generalmente sobre la espalda atado con una piel, o sujetándolo sobre su regazo para que descansara. En cualquier caso, la participación de los/as hermanos/as mayores en la atención y cuidado de los menores era muy destacada y permitía liberar a la madre de tal responsabilidad para que se pudiera dedicar al resto de tareas cotidianas (mariscar, remar, cocinar, recoger junquillo, hacer cesta, etc.).

Pasado el primer año crítico de vida, una vez que el niño o la niña caminaba y comía solo/a, la educación infantil estaba orientada hacia la autosuficiencia, sin que el cariño y la protección estuvieran ausentes. De acuerdo a la propia observación, los besos no parece que formen parte de la costumbre; sobre el particular Gusinde ofrece versiones contradictorias, en unos casos dice que son muy abundantes de la madre al hijo pequeño (1951, p. 256) y en otros que "un verdadero beso tampoco es usual" (1991 [1974], p. 369); pero las caricias están muy presentes tanto en la actualidad como en distintos testimonios históricos. La inactividad y el silencio que los pequeños mantenían durante las muchas horas que pasaban en la canoa reprimía las ganas de juego y contrasta con la actividad lúdica desarrollada cuando llegaban al campamento. Los juegos eran sencillos en cuanto a las normas, dinámica y material empleado (golpear con las manos una guata o estómago de lobo inflado a modo de pelota, competir dentro de la choza por pareja a ver quién es el más rápido en atar y desatar una canoa en miniatura a un poste o al mismo dedo, corretear en la playa, columpiarse); sin olvidarse de aquellos otros camuflados entre las tareas que los mayores les encargaban (acarrear leña, agua, mariscar, hacer canasto), ya que, desde muy pequeños los acompañaban en su quehacer e imitaban sus comportamientos, incorporándoles imaginación y sentido lúdico para hacerlos más atractivos y divertidos.

Sea como sea, lo que se desprende de los testimonios históricos (Emperaire, 1963, pp. 217218; Gusinde 1991 [1974], pp. 361-365, 374$375,377-381$ ) y de la experiencia vivida por los kawésqar de mayor edad en la actualidad (Gabriela Paterito y Francisco Arroyo), es una educación infantil marcada por la obediencia, en donde nada ordenado por los mayores era cuestionado; por la ausencia de coacción y castigos físicos a edades tempranas al entenderse que aún no se

4 Este dato hace entender que se trata de la parte sur del territorio kawésqar, ya que no hay guanacos en los canales del norte. 
distingue entre lo que es o no es adecuado; y por la diferenciación sexual en las tareas distintivas que niños y niñas realizaban en consonancia a lo que hacen hombres y mujeres.

Ausentes hoy día los rituales de iniciación del pasado, el kalakai y el yenchiháwa (o yinciháua), ampliamente descritos por Gusinde (9991 [1974]), no solo no existen sino que también han desaparecido de la memoria. De los relatos escritos nos queda al menos constancia del importante papel ejercido por la performance corporal, con las representaciones, juegos de imitación y ejecuciones dancísticas, los amplios momentos de inmovilidad en posición de cuclillas, las privaciones alimenticias o las transformaciones por medio de máscaras, pinturas y ornamentos. Aspectos todos ellos que, además del valor simbólico, poseía sentido práctico en lo que implica disciplina corporal (para aguantar quieto en espacios reducidos o soportar la hambruna), diferenciación sexual e integración grupal.

El kalakai constituía un proceso ritual de iniciación a la vida adulta en el que la colectividad se involucraba para completar, intensificar y corregir, si fuera necesario en algunos casos, la educación que hasta entonces había recaído en la exclusiva responsabilidad de los padres, tanto en actividades prácticas de supervivencia como en los valores y normas sociales que facilitara la futura convivencia con los suyos (Goiri, 1997, p. 23). Ritual que incluía diferentes fases: selección de candidatos/as, estancia en la gran choza y aprendizaje de tareas, y confirmación final del aprendizaje, todo lo cual podría durar entre seis y diez semanas; aunque en algunos casos que necesitara más tiempo para la asimilación de conocimientos se podía ampliar varias semanas más.

Una vez que se reunía a un número suficiente de candidatos/as de entre catorce $y$ dieciocho años, que oscilaba al parecer entre cuatro y doce, se construía una gran choza (at. ék'wil, en la transcripción de Gusinde) de unos $13 \mathrm{~m}$. de largo por $4.5 \mathrm{~m}$. de ancho y $3 \mathrm{~m}$. de altura máxima, con un fogón en el centro, que acogía a un número medio de participantes; y en la cercanía algunas chozas familiares de pequeño tamaño donde se preparaban comidas y aseaban a los candidatos/as para luego ser conducidos junto a su padrino o madrina (parientes o amigos cercanos) hasta la gran choza, donde entraban sin ninguna formalidad y se sentaban todos/as para quedar a las órdenes del jefe o conductor de todo el proceso ceremonial. Una vez dentro, a los/as participantes se les embadurnaba todo el cuerpo con polvo blanco seco para luego pintarlos y añadirles algunos ornamentos. (Gusinde, 1991 [1974], p. 394).

Junto con la instrucción moral, padrinos y madrinas acompañaban a los/as candidatos/as fuera de la gran choza para ejercitarlos en las tareas que debían depurar. Los jóvenes aprendían a lanzar arpones, manejar la honda, el arco y la flecha, la lanza y el venablo, el garrote, la red lobera, a acechar animales, a talar troncos, desprenderles la corteza, despellejar lobos marinos, etc. Y las jóvenes a recolectar moluscos marinos, cangrejos, buscar bayas y hongos, reunir leña apropiada, trenzar cestos, preparar adornos, collares, etc.

Cada día de vuelta a la gran choza por la tarde (sobre las 14:00 o 15:00 h.) tenían unas dos o tres horas de descanso que las pasaban acuclillados en silencio en sus puestos. Mantener la debida postura del cuerpo sin movimiento alguno, evitando mirar a los lados o rascarse para aliviar el molesto picor, era al parecer una parte importante de la instrucción. No obstante, tras ello podían también danzar y entonar cantos todos juntos, primero apretados en círculo con pasos cortos y lentos, y luego con mayor libertad de movimiento golpeando una vara sobre el suelo. La presencia de bromistas que animaran las reuniones era igualmente muy apreciada, llegado el momento.

La pérdida de peso debido a la exigua dieta que mantenían durante todo el proceso de iniciación era la constante, constante que se rompía la última noche con una gran y animada comida, tras la cual la iniciación llegaba a su término. Ya por la mañana las familias se embarcaban por separado para abandonar el lugar en distintas direcciones (Ibid.: 398-401).

Si bien el kakakai era un ritual iniciático sin distinción de sexo, una vez que se pasaba por él, tenía lugar otro ritual esta vez secreto y exclusivo de los hombres: el yenchiháwa. Aprovechando la eventualidad de encontrar una ballena varada que proporcionara alimento durante varias semanas, como ocurría en el kalakai, a veces también se organizaba el yenchiháwa, para lo cual se 
construía igualmente una gran choza, coloreada de rojo en su interior, esta vez para uso exclusivo de los hombres, y a unos doscientos metros se construían chozas habitación de forma cónica para las mujeres, coloreadas de blanco en su interior, en donde éstas preparaban los alimentos tras haberlos recolectados.

Los hombres fabricaban y usaban máscaras de corteza de haya de forma cilíndrica o cónica de carácter fálico pintadas de blanco con dos orificios para los ojos, las cuales permanecían cubiertas y ocultas a las mujeres cuando no eran utilizadas y las invitaban a visitar la gran choza, siendo quemadas finalmente al concluir el ritual. Su portador se pintaba el cuerpo al completo igualmente de blanco, con dos trazos rojos horizontales sobre el labio superior e inferior que se extendían por las mejillas hasta los lóbulos de las orejas entre los candidatos novatos y un solo trazo más grueso entre los más veteranos. ${ }^{5}$ Además se adornaban con tiras de cuero con plumón blanco de albatros rodeando la frente a modo de diadema, así como también las muñecas, brazos, piernas y cuello ${ }^{6}$ (Ibid.: 472-491).

Irreconocibles con las máscaras, pinturas y adornos, los hombres aparecían a modo de espíritus en el campamento de las mujeres y los niños, compuesto por las chozas habitación, donde brincaban ante sus asombradas espectadoras dando saltos a los lados con los brazos caídos abajo o extendidos lateralmente. De manera ocasional si encontraban a una mujer descuidada la conducían al interior de la gran choza con un trozo de piel por la cabeza que le impidiera ver, y echada sobre el suelo era sometida al griterío de los hombres que danzaban en torno a ella pasándole

5 Además de este modelo de pintura se citan otros más con líneas rectas y ondulantes, así como el color rojo y negro (Ibid.: 502).

6 Este ritual está relacionado con el mito de origen de la mujer luna, esposa (o hermana según una variante) del hombre sol. Dice así:

Todos los años se reunían las mujeres para su yinciháua y presentaban a los espíritus con diferentes máscaras y pintura. Un día hubo una gran disputa entre el Sol y la Luna, en la cual todos los hombres se fueron al bando del Hombre Sol y todas las mujeres al de la Mujer Luna. Un enorme incendio estalló, y todas las mujeres fueron aniquiladas junto con la choza yinciháua y todas las máscaras. En ese entonces todas las mujeres estaban pintadas porque habian participado la punta del arpón por su cuerpo a modo de juego intimidatorio. También danzaban en el exterior de la gran choza, sin retirarse más de $10 \mathrm{~m}$. de ella, así como en su interior. Las mujeres además de espectadoras, podían acompañar a veces a los hombres en sus danzas, formando grupos separados sin mezclarse con ellos. De otro modo el grupo de mujeres entonaba cantos y danzaba formando filas y golpeando el suelo con un bastón mientras los hombres observaban en cuclillas, para seguidamente intercambiar los papeles. Hombres y mujeres danzaban también por parejas con el rostro muy junto imitando los movimientos de determinados animales como ballenas, lobos marinos, albatros, patos, gaviotas, etc. (Ibid.: 502517).

Además de las danzas y juegos de imitación animal, que suponían momentos de diversión y esparcimiento junto a las mujeres, los hombres, bajo la dirección de quien los custodiaba, realizaban ejercicios artesanales y eran sometidos a severas restricciones: tras dormir apenas cinco o seis horas, eran despertados para adoptar la posición en cuclillas ligeramente inclinados hacia adelante, con los brazos cruzados por delante y la mirada fija en un punto; bien temprano se bañaban en las frías aguas de algún canal cercano para regresar de nuevo a la gran choza y mantener la posición en cuclillas junto al fuego; inmóvil y sin apoyo permanecían por tiempo prolongado en esta forzada posición, sin apenas consumir alimentos, y sin que pudieran manifestar queja alguna (Ibid.: 511-519).

El control sobre el cuerpo logrado a base de mantener posiciones forzadas y estáticas, soportar cualquier incomodidad y privarse de

en la celebración, y se transformaron en animales, por eso hoy día los hay de distintos colores. El gran incendio fue ocasionado y fomentado por los mismos hom bres, y todo se quemó. Los hombres, que eran los más fuertes, vencieron a las mujeres, tomaron posesión de todo lo que antes les pertenecía e hicieron todo de la misma forma como habian observado que hacian ellas. Tras el enorme incendio, la Mujer Luna, con el Arcoiris, ascendió al firmamento, seguida del Hombre Sol, sin que ambos pudieran darse alcance; hasta la fecha permanecen en el cielo. Hasta el presente día las mujeres no deben saber que estuvieron en posesión del yinciháua y que las personas que aparecen son, en realidad, sus propios hombres enmascarados. (Gusinde, 1991 [1974], p. 485) 
alimentos, todo ello sin protestar, implicaba una disciplina útil para ser extrapolada a otros órdenes de la vida cotidiana, vida canoera en donde era preciso estar habituado al reducido espacio que permitía la canoa, y sobre todo vida rodeada de incertidumbre en donde había que estar preparado para dormir acurrucado en un pequeño refugio improvisado para hacer noche, o soportar eventuales momentos de hambruna al no encontrar alimentos en determinados lugares por donde pasaban. La experiencia de Gabriela Paterito así lo manifiesta: ahí pasamo un hambre, porque por áhi en ese lugar no hay marisco, no hay maucho, no hay chorito, el lugar e' feo, cuando sube la marea está tapao la rama el agua.

Con la limitación que supone no disponer de datos de primera mano y contar tan solo con los testimonios extraídos de la literatura sobre rituales ya desaparecidos, podemos deducir, no obstante, que tanto en el kalakai como en el yenchiháwa, el cuerpo con su envoltura y en movimiento se presenta como un sistema de comunicación portador de sentido (Birtwistell, 1952; Knapp, 1985). A través de las pinturas faciales se distinguen los participantes nóveles de los veteranos en el yenchiháwa; con las máscaras fálicas se pretenden atemorizar a las mujeres evocando espíritus subterráneos; por medio de danzas hombres y mujeres se divierten emulando animales conocidos, se lanzan mensajes mutuamente con sus representaciones alternas; se distinguen del otro/a formando grupos por separado con sus patrones coreográficos; y se manifiestan de manera más personal con las ejecuciones libres. Todo ello sin entrar en el lenguaje concreto que se puede derivar del movimiento rítmico o de los cuerpos pintados ${ }^{7} \mathrm{u}$ ornamentados, por carecer de los códigos culturales para su interpretación, ni en la posible interpretación que también puede tener si su orientación busca destinatarios divinos, además de los humanos. Cuerpos transformados, movilizados con ritmo que sin duda dicen algo de algo.

Pero además es preciso apreciar el cuerpo dentro de estas prácticas rituales como un lugar de control y de poder (Foucault, 1984). Es a través del sacrificio corporal como se provoca

7 Las pinturas corporales pueden ocultar otras dos interpretaciones posibles relacionadas con el tabú y el el aleccionamiento de la persona, que induce la consecución de hábitus (Bourdieu, 1988) de control personal para soportar carencias e imperativos ambientales, con el que, si no controlar el mundo que los rodea y en donde se encuentran, sí al menos sobrevivir en él.

Al margen de esos rituales ya desaparecidos, de los kawésqar contemporáneos sabemos que el reconocimiento como persona adulta con autorización para casarse y capacidad para mantener una familia, dependía no solo de la edad sino muy especialmente de las habilidades y destrezas desarrolladas para procurarse la autosubsistencia y llevar una vida independiente. Como bien expresa Alberto Achacaz, kawésqar fallecido en 2008: Nosotros pasábamos a ser hombres cuando sabíamos andar $\left(\right.$ chalac $\left.^{8}\right)$ y conocíamos los canales. (cfr. Vega 1995, p. 80).

\section{VESTUARIO Y ORNAMENTOS, ALIMENTACIÓN, HIGIENE Y SALUD, Y SEXUALIDAD}

En otro orden de cosas, uno de los aspectos más sobresalientes que más han llamado la atención de los navegantes y exploradores del pasado ha sido la casi completa desnudez de los nativos de los canales patagónicos, apenas cubiertos para el entorno en que se hallan.

Sobre el vestuario son muchas las referencias históricas halladas, las diferencias y matices la podemos encontrar acudiendo a las fuentes originales (Jofre de Loaysa, 1526; Pedro Sarmiento de Gamboa, 1579-80; Thomas Cavendish, 1587; Sebald de Weert, 1598; Oliver de Noort, 1598; John Narborough, 1617; M. de Gennes, 1696; Amadeo Francisco Frezier, 1712; Antonio de Córdova, 1785-1786; Parker King, 1826-1827; Fitz-Roy, 1831-1834; Richard W. Coppinger, 1879; Cooper; Skottsberg; Borgatello; Bougainville; John Byron; cfr. Gusinde 1991 [1974], pp. 23-67, 190-193), pero en general hombres y mujeres untaban sus cuerpos con grasa de foca, lobo marino o animales similares, en ocasiones se embadurnaban con barro o arcilla, y se cubrían tan solo con una capa de piel de lobo marino, foca, ciervo, guanaco, coipo, nutria $\mathrm{u}$ otros animales apropiados, que ataban al

linaje.

8 Transcripción errónea de c'élak (duro, valiente, fuerte). 
cuello con una cinta de cuero, tripa de pescado o algún otro material, dejaban caer aproximadamente hasta las caderas, y más que para el frío protegía del agua y el viento, al no quedar fija, descansar sobre la espalda y poderse mover sobre los hombros según convenga. Los hombres cubrían al parecer sus genitales con un trozo triangular de piel atado a la cintura, aunque hay también quienes, como Jofré de Loaysa (cfr. Gusinde, 1991 [1974], p. 23) afirman que tanto hombres como mujeres llevaban sus vergüenzas de fuera. $\mathrm{Y}$ los niños $\mathrm{y}$ niñas habitualmente mantenían su completa desnudez en la vida diaria hasta los aproximadamente 12 años de edad. Retrato sobre la tradicional forma de vestir de los antiguos kawésqar, con el que coincide también Emperaire (1963, pp. 133-139), y otros autores (Lautaro Navarro, 1894; Barros \& Armstrong, 1975, p. 44; Hammerly, 1952, p. 150; Aylwin, 1995, p. 16; Lausic, 1993), ya sea con sus propios testimonios o por los testimonios históricos que ofrecen.

Todavía Alberto Achacaz, dejó escrito cómo fabricaban las capas con las que se cubrían, uniendo dos pieles de lobo marino, y las frazadas uniendo cuatro de ellas, las cuales eran curtidas previamente sobándolas durante unos dos días con las manos. Tiempo ese (hasta mediados del siglo XX) en el que, como nos cuenta, aún no existían zapatos y andaban a pie pelado (cfr. Vega, 1995, pp. 27-34). Tal circunstancia, no obstante, sería combinada con el uso de la ropa occidental que desde los primeros contactos y de manera progresiva se fue imponiendo en la población, siendo habitual hasta el tercer tercio del siglo XX, como lo refieren Gabriela Paterito y Francisco Arroyo en Puerto Edén, al recordar cómo en su niñez y juventud andaban a "pata pelá" $e$ intercambiaban ropa y viveres con los tripulantes $y$ viajeros de los buques que iban de paso por los canales, allá por los años 50.

Cuando me crecí faro San Pedro cambiaba ropa por cuero nutria o lo cargaba, ya sabía que en buque unos marino cambio cuero nutria, antes se cazaba cuero nutria, eso alcancé ver, sí, más antiguo no sé, eso es que no. [...] (¿era la misma ropa que tenemos ahora aproximadamente?) menos zapato, eso sí que no teníamo zapato, hasta cuando teníamo 30 año todavía andaba a pata pelá, nunca usé zapato, [...] no había tampoco, total que los pie están costumbrao asi que yo andaba a pata pelá, andá caminando por la piedra, helada, no hacía nada, no se sentía frío tampoco, era costumbre de nosotro. [...] y otra cosa que usaba era una bolsa de harina, cuando lo vaciaba lo cosian y hacían un vestio para la mujer que sabian poco, en esa clase de género no se rompía tampoco, podía andar trayéndolo un año que no hacía nada, yo usé eso igual, [...] (¿Los niños en su época andaban más bien desnudos?) Sí, desnudo, crecímo así no má desnudo, claro comiendo bien carne lobo, en vece este, comíamo carne lobo asi que qué frío va tener, siempre andabamo así, cuando estaba en un puerto sí, pero cuando ya quería salí navegá ya se ponía ropa abrigarse, eso era lo que usabamo nosotro. [...] lo mayore ya anda con su vestido. (Entrevista a Gabriela Paterito, 7 de enero de 2009).

Del estudio realizado por Carleton S. Coon en 1960 (cfr. Gusinde, 1991 [1974], pp. 86-87), se desprende la idea de que los kawésqar estaban muy bien adaptados al frío. En la actualidad no contamos con estudios comparativos al respecto, pero por cómo visten y viven en estos momentos, las diferencias pensamos que ya no deben ser muy significativas con respecto a los chilotes y demás colonos residentes en Puerto Edén con los que comparten el mismo estilo de vida. Sin embargo, la lógica del austero vestuario de los antiguos kawésqar ya fue observada por Emperaire (1963) y por Gusinde (1951) al considerar mucho más eficaz cubrir el cuerpo con una capa protectora de grasa, una ligera piel animal y calentarse al fuego, que usar vestidos que estén todo el tiempo húmedos o empapados, en un ambiente donde la lluvia y el viento son una constante a lo largo de todo el año; circunstancia que, como demuestra la experiencia histórica, motivó un significativo aumento de la morbilidad y mortalidad en la población.

En un país en el que llueve 280 días al año y donde el viento sopla casi constantemente, es preferible una simple 
capa protectora de grasa sobre la piel desnuda y algunos mantos de pieles de animales antes que vestidos todo el tiempo húmedos o empapados. (Emperaire, 1963, p. 87).

Los indios estaban acostumbrados magníficamente a su extraordinario clima y que desnudos tenían la ventaja de recibir directa y abundantemente el calor de la hoguera en la cabaña o en la canoa. [...] los fueguinos protegen su cuerpo contra el viento y la lluvia sólo por medio de una manta de piel, colocada suelta, llevando al mismo tiempo por modestia un sencillo taparrabo. Los vestidos europeos se ciñen mucho al cuerpo, impiden la transpiración de la piel, se van ensuciando poco a poco, no se le puede hacer una limpieza a fondo y no es posible desprenderse de ellos cuando están chorreando de humedad; [...] manta de piel, [...] con ella solo habian vivido nuestros fueguinos durante muchos siglos, fuertes, sanos y contentos. (Gusinde, 1951, p. 122).

A partir de los años 70 los pasajeros y marinos que transitaban por los canales patagónicos 9 conmovidos por la desnudez y las carencias de los nativos les regalaban ropas, alimentos y algunos enseres, o los cambiaban por pieles de nutria (Martinic, 2006, p. 808).

En cuanto a los ornamentos tradicionales, representados por los adornos y la pintura corporal que, según Emperaire, 1963, pp. 140-141, tenían un carácter más simbólico que decorativo como forma de expresión ligada al mundo invisible, prácticamente desaparecieron a mediados del siglo XX. Son bastantes los relatos históricos (Ladrillero, García Martí, Bougainville, Pedro de Sarmiento, Fitz Roy; cfr. Emperaire, 1963; Gusinde, 1991 [1974]; Lausic, 1993; Cárdenas et al. 1993) que apuntan a la pintura corporal como la técnica ornamental más empleada, con el uso destacado de los colores blanco, rojo y negro para diversas manifestaciones de la vida cotidiana y en el ámbito ritual. El blanco

9 El flujo de barcos por los Archipiélagos Patagónicos superó los 500 en 2002 (Martinic, 2004, p. 164).

10 Según Fitz-Roy: Las plumas blancas, o el plumón blanco en la cinta es signo de hostilidad, o de estar preparado era obtenido a través de la piedra caliza y mediante el machacado de conchas de moluscos, el rojo de la tierra o arcilla, y el negro del carbón; polvos colorantes que mezclados con aceite animal (de foca, lobo marino, pescado, etc.) untaban sus cuerpos de diversas formas: con puntos, círculos, rayas, cobertura completa. Colores interpretados de diferentes maneras según los autores: el blanco es relacionado con la alegría (Gusinde, 1991 [1974], pp. 206-207, 561), con la guerra (Agostini, 1941, p. 69; Fitz-Roy, cfr. Gusinde, 1991 [1974], p. 562); el rojo con la alegría (Agostini, 1941, p. 69), con la paz (Fitz-Roy, cfr. Gusinde, 1991 [1974], p. 562), con motivos místico religiosos (Gusinde, 1991 [1974], pp. 206-207, 561), con la muerte de un familiar (Achacaz, cfr. Vega, 1995, p. 54); y el negro con el luto y el tabú (Fitz-Roy, cfr. Gusinde, 1991 [1974], p. 562; Agostini, 1941, p. 69)

Como adornos complementarios son citados por ejemplo: los collares y brazaletes de muñeca y tobillo hechos con conchas de caracol o de trocitos de hueso unidos por hilos de tripa, empleados por hombres y mujeres (Skottsberg, cfr. Gusinde, 1991 [1974], p. 216; Barros \& Armstrong, 1975, p. 744); o el tocado de plumas de diferentes aves (caiquenes blancos, avutarda, pato quetro, gaviotas, etc.) usados por los hombres (Fitz-Roy ${ }^{10}$, Córdoba, cfr. Gusinde, 1991 [1974], pp. 196-197, 209, 562; Alberto Achacaz, cfr. Vega 1995, p. 55).

En cuanto a la alimentación, resulta convincente la interpretación que ofrecen Orquera y Piana (1995, pp. 219-221, 232-233, 382-391) al basar la dieta y subsistencia de los antiguos kawésqar en el mejillón ${ }^{11}$, recurso abundante y de fácil adquisición por todo el litoral marino, y en el lobo marino, por su nutriente graso que resulta esencial para la adaptación al clima frío. Versión que coincide con los datos aportados por Gusinde (1991 [1974], pp. 51, 62, 294-301, 321-333) en base a los testimonios históricos recogidos de Córdoba, Fitz-Roy, Du Plessis, Bird, Barros Arana, Skottsberg; así como de su propia experiencia, en donde, como alimentos más consumidos destacan los moluscos (cholgas, choros, almejas, mauchos, locos, erizos, centollas) y los mamíferos

para la guerra. (cfr. Gusinde, 1991 [1974], p. 562).

11 Acompañado de más productos, dado que la dieta a partir de mariscos y pescados no satisface los requerimientos nutricionales de una persona adulta. 
marinos (lobo de mar, foca, nutrias); ampliándose la dieta con pescado (róbalo, pejerrey, congrio), aves (cormorán, caiquén, pato quetro, pato lile), mamíferos terrestres (huemul, guanaco), ocasionales ballenas, y productos vegetales de temporada (calafate, murtilla, hongos, apio silvestre, etc.) o algas marinas (cochayuyo, luche).

También los testimonios de los actuales kawésqar de mayor edad sostienen que el marisqueo, complementado con la carne y grasa de lobo marino, constituían la base de su alimentación. La primera alternativa era el recurso más fácil y eficiente por la cantidad de cholgas, choros, almejas o erizos existentes; actividad convertida en la constante diaria. Y la segunda cubría las necesidades dietéticas de materia grasa, imprescindible para soportar los rigores del clima. El resto de actividades destinadas a la obtención de alimentos aparecen como estacionales o esporádicas: recolección de bayas, empleo de trampas para aves, recogida de huevos, caza de huemul. de lobo marino.

Anda trayendo su maucho, su cholga, con su canasto que hice, con esa misma, y ese cuando tiene má' cholga, má' marisco, mejor todavía para ello, entonce otro si falta ella lo repartía, asi vivía ello; [...] y ello comía to lo' día marisco, puro marisco, almeja y cholga. (Entrevista a Gabriela Paterito, 7 de enero de 2009).

Sobre el modo en que consumían los alimentos de origen animal, generalmente casi todos eran pasados por el fuego por poco tiempo que fuera, salvo algunos como los erizos y las machas (Emperaire, 1963, pp. 121-131), aunque a veces los testimonios son contradictorios y hay quienes afirman que el marisco y el pescado se comía de ordinario crudo, o que los mejillones se comían crudos o asados indistintamente (Barros Arana \& Skottsberg, cfr. Gusinde, 1991 [1974], pp. 323-324). En cualquier caso, de los testimonios históricos citados y de la información obtenida de los propios kawésqar sobre la preparación de los alimentos deducimos tres aspectos básicos: la dependencia del fuego, la práctica de asado y la no conservación, aunque sí previsión para llevar alimentos de reserva en las largas travesías.

Invariablemente las comidas que citan
Gabriela Paterito y Francisco Arroyo en sus relatos son pasadas por el fuego; aunque sabemos que de vez en cuando alguna que otra almeja o incluso cholga o choro se comía cruda; por lo regular, a excepción de los erizos y las bayas silvestres, se cocina todo, y la manera habitual de hacerlo es asado, exponiendo directamente al fuego las piezas que se vayan a comer, ya sean mariscos, o carne de mamíferos o de aves; el uso de recipientes para cocer es fruto de los préstamos culturales con quienes vinieron de fuera. Las reservas eran mínimas, los mariscos no se conservaban por más de dos o tres días, aunque, como nos comentan de las mujeres antiguas, ellas eran más previsoras y siempre contaban con alguna reserva de alimento, especialmente durante las largas travesías, para salir de algún apuro imprevisto; las personas con las que convivió Gabriela en su juventud eran menos previsoras que las antiguas, nos decía. Nosotro un rato que lo llenamo marisco ya en la tarde ya no teníamo, pero la persona antigua no, po, ya tiene diferente su relación, lo reserva. (Entrevista a Gabriela Paterito, 7 de enero de 2009).

Es tras el contacto con los chilotes cuando se empieza a practicar el secado de algunos alimentos, especialmente cholgas, aunque con una finalidad comercial. Con la harta presencia del humo en el interior de la choza o at, circunstancia muy comentada en la literatura (Emperaire, 1963, p. 255; Gusinde 1991 [1974], p. 179; Lausic, 1993, p. 28; Vega, 1995 , p. 18) y entre los actuales kawésqar, con los problemas derivados para los ojos y sobre todo para los pulmones, resulta curioso cómo estando tan habituados a él no lo emplearan para ahumar alimentos de autoconsumo y así conservarlos durante semanas y aún meses, habida cuenta de que, aunque los recursos eran generalmente abundantes, al menos en marisco, no estaban ausentes los lugares y momentos en donde se pasó hambre, bien porque el sitio no daba de sí o porque el mal tiempo impedía salir.

Ahi pasamo un HAMBRE, porque por ahi en ese lugar no hay marisco, no hay maucho, no hay chorito, el lugar e' feo, pasamo mal rato, total que no había qué comer, pasamo hambre, tiempo invierno, y mala marea, la marea no bajaba 
nada, ni una cosa, obligao aguantarse así. (Entrevista a Gabriela Paterito, 7 de enero de 2009).

En cualquier caso, el fuego ocupa un papel crucial para la supervivencia en los canales y así se desprende de los relatos nativos, al aparecer como constante en la vida cotidiana: "fósforo sí que no podía faltar, ese e' único e' má' principá”, decía Gabriela. Fuego obtenido por medio de fósforos, no por el procedimiento antiguo de percusión de piedras (cuarzo y pirita), como se cita en la literatura (Emperaire, 1963, p. 121).

De ordinario, en la distribución de tareas para la obtención de alimentos, los hombres se encargaban de las actividades de caza y pesca y las mujeres de las recolectoras tanto animales como vegetales. No obstante, la provisión de alimentos era una tarea compartida. Generalmente del marisqueo por el litoral se ocupaba más la mujer y el hombre de los distintos tipos de caza, ya fuera destinada a mamíferos o aves; en la pesca mediante corral participaban ambos. La preparación y consumo de alimentos cuando navegaban de un lado para otro cada cual lo hacía de modo individual; y una y otro asaban directamente en el fuego central de la choza las cholgas o productos que se fueran a comer, hasta hartarse.

Acerca de las costumbres alimenticias, Gusinde (1991 [1974]) nos indica que la cholga, así como la lapa, el loco y otros moluscos se preparaban en pocos minutos cociéndolos sobre las ascuas. A los erizos les sacaban las cinco lenguas con los dedos para comerlos crudos y beber el jugo que quedaba dentro del caparazón. El pequeño lobo marino o foca se troceaba y se asaba en pequeñas porciones sobre las brasas, o se colgaba en una varilla cerca de la llama para que se seque. La grasa de ballena que gotea de la carne asada se recogía en una concha de mejillón para beberla directamente, sin embargo rechazaban todo tipo de sangre animal. El cormorán una vez desplumado era asado también sobre las brasas. Los huevos de aves se colocaban sobre las cenizas calientes o las brasas hasta dejarlos duros para después descascarillarlos y comerlos. Curiosamente, nos dice que "Rara vez comen pescado y, en caso de hacerlo, lo colocan sobre las brasas". Del róbalo asaban las huevas y el hígado en la ceniza caliente. Tampoco el guanaco y el huemul eran habituales piezas de caza, siendo más accesible las crías del lobo marino de dos pelos. La grasa y la carne de ballena era conservada durante tres o cuatro meses enterrada bajo el suelo a unos $120 \mathrm{~cm}$. de profundidad. Preparaban también una especie de embutido introduciendo en el esófago del cormorán (de unos $20 \mathrm{~cm}$. de largo) los riñones, corazón, pulmón, ovarios y grasa de la misma ave, colocándolo durante unos 20 minutos sobre el fuego para comerlo seguidamente o dejarlo para el día siguiente. Algunas algas marinas como el cochayuyo y el luche, que durante el trabajo de campo comprobamos cómo las consumían hervidas, Gusinde informa que no las comían en su época, aunque eran muy apreciadas por los chilotes. Cuenta que la mayoría de los adultos eran muy selectivos y no solo pensaban en llenar el estómago sino en disfrutar de la comida, mostrándose ávidos especialmente por la tierna carne del lobo de dos pelos, las nutrias jóvenes, el huemul o el guanaco, que consideraban un manjar; así como las grandes cholgas y centollas. Despreciaban, sin embargo, a los animales viejos, así como a las gaviotas y demás aves de rapiña, la carne de zorro, el coipo, las ratas les daban asco, y a los delfines ni los tocaban al pensar que la ingestión de su grasa provocaba fuertes dolores corporales. Como productos vegetales de temporada (finales del verano) consumían también bayas como el calafate, la murtilla o el empetrum, entre otras; determinados hongos, los tallos del pangue, o el apio silvestre (Ibid.: 325-333).

En cuando al horario y lugar de las comidas nos dice lo siguiente:

En el día, durante todo el año, difícilmente se puede determinar para las familias un momento preciso para sus comidas. [...] los desplazamientos dependen del tiempo cambiante y siempre nuboso; [...] en general se consume la primera comida completa después del amanecer; eso puede ser a las siete o bien una o dos horas más tarde. Antes de abordar la canoa cada miembro de la familia se sacia. [...] A medio camino en la travesía, la gente suele no comer, para no desbalancear la vacilante embarcación con los preparativos de una comida. Recién tras el desembarque e instalación de la nueva choza comienza 
para todos la segunda comida, que en realidad es la principal y que usualmente se extiende largo tiempo. (Ibid.: 333).

Tanto la dieta como las formas de preparación de los alimentos y los horarios, experimentaron un notable cambio a partir del asentamiento estable de los kawésqar en Puerto Edén, en compañía de los colonos chilotes y de las FACH (Fuerza Aérea de Chile) que, en un principio y durante años, facilitaron viveres de manera gratuita, aunque luego los kawésqar tuvieran que trabajar para obtener dinero y acceder a ellos ${ }^{12}$. Así se introdujeron nuevos productos (arroz, pasta, harina, frutas, verduras, conservas) en la dieta habitual; el agua para beber perdió terreno ante las bebidas refrescantes o el vino; el paladar se fue acostumbrando a los sabores amargos del mate o el café, al dulce del azúcar, a los picantes del chile y otras especies antes desconocidas, o a la carne seca (charque) que en un principio resultaba incomestible y se le daba a los perros; del asado se pasó a la cocción o hervido en latas u ollas que incorporaron como utensilios; y el ahumado de algunos alimentos como la cholga o el pescado se hicieron práctica común. El horario para las comidas, repartido en el pasado entre el momento antes de salir a navegar por la mañana temprano, y el momento de regresar o montar el campamento ya por la tarde, pasó a un horario más dilatado en donde, con la vida sedentaria, cualquier hora es buena para comer (Emperaire ${ }^{13}, 1963$, pp. 132-133) y para consumir alcohol, con las graves consecuencias que se derivan para el deterioro de la salud y la vida social. También la costumbre de redistribuir los productos de la cacería entre todas las familias que formaban el campamento, ya fuera estable u ocasional, es echada

12 En la actualidad, la opción de conseguir dinero con el que comprar los viveres (harina, arroz, pasta, frutas, verduras, etc.) que se venden en las tiendas de Puerto Edén, llegados en los barcos semanales que cubren el trayecto desde Puerto Natales a Puerto Montt y viceversa, les ha hecho pescar y sobre todo recoger moluscos y crustáceos y ponerlos igualmente en venta. La otra opción ha sido trabajar en el secado de la cholga para su comercialización, actividad en la que todas las familias kawésqar de Puerto Edén se han involucrado en mayor o menor grado, pero la total dependencia del habilitador que se las compra para introducirlas en el mercado y al mismo tiempo les vende los viveres a precio de usura para que se mantengan durante el tiempo de trabajo, les ha hecho entender a todos que no merecía la pena, aunque algunos sigan en esa faena a su pesar. en falta actualmente por los mayores que observan cómo ha disminuido las muestras de solidaridad. Así lo refiere Francisco Arroyo:

Ya se agarraba lobo dice que lo rompía to ahi cosio; tiene que comer to junto, to eso qu'está carpa pa allá, to eso lejo, uno se va repartir a cabro chico, cabro no tan chico, cabro con 14, 15 año, ese tenía que repartir peazo carne lobo, ante no come solo, tiene que comer to junto, si tenía ello algo tenía que repartir, to lo mismo; [...] no le dá ná, prefería que l'otro está mirando y l'otro está comiendo, [tose] tenía su costumbre ello, hay que comer to junto, si no tiene otra cosa come na má to, to lo mismo; to pa comer, aunque sea poco igual lo reparte poquito. Ahora no, ahora estamo costumbrao como huilliche, solo aquí, aunque esté muriendo aquí al lao de la casa, como acá al lao está comiendo bien uno, ante no, ante había costumbre d'eso, el mayor lo repartía to pa comer. (Entrevista a Francisco Arroyo, 15 de enero de 2009).

Y más adelante nos informa del reparto de alimentos recibidos gratuita y periódicamente por el Estado chileno, lo cual indujo al sedentarismo y al consumo progresivo de alcohol:

Eso era ración de alimento pa nosotros, para to que'stamo ahí, pa repartila; a la semana te daba uno o do' kilo cosa pa pasá la semana y despué que

13 Así como los kawésqar asentados en Puerto Edén, sobre todo cuando el mal tiempo impedía salir a navegar, se la pasaban entre la comida y el sueño de manera permanente $e$ ingerían grandes cantidades de alimento en el interior de sus chozas, tenían también capacidad para aguantar el hambre si las circunstancias imponían un ayuno forzoso.

Toda hora es buena para comer. [...] Si el día debe pasarse en la inacción y la alimentación es suficiente, el tiempo se divide entre comer y dormir, en la propia choza o de visita en las chozas vecinas. [...] Así como es capaz de absorber una enorme cantidad de alimento, con una capacidad que parece ilimitada, asi también el indio alacalufe es capaz de resistir al hambre cuando circunstan cias como el mal tiempo le imponen un ayuno forzado. Emperaire (1963, pp. 132-133). 
termina iba buscar arriba; cada semana venía, traía toa las cosa; hierbesita, arró, fideo, garbanzo, lenteja, mote, ciruela, pilonsillo, aceite, manteca, hierba mate traía por bolsa, puro bolsa salía ante, café igual, té parece que no, puro café llegaba, jabón pa lavar ropa. La gente casi nunca salía pa fuera, estar ahí na má;

ante no tomaba mucho el vino, to estamo sano, a vece cuando viene el barco, a vece tomamo pero no e' tanto como ahora, ahora to el tiempo que está acá lo tomamo harto, casi morimo con eso; tomamo mucho, cinco, sei' día sin comer, ya no resiste el cuerpo (Entrevista a Francisco Arroyo, 16 de enero de 2009).

Por los relatos escuchados, el verano traía consigo ligeros cambios en la dieta con la aparición de frutos silvestres y la caza de mamíferos terrestres; $y$ en el invierno no eran raros los momentos de hambruna, motivados a veces por la imposibilidad de salir a cazar, pescar o mariscar debido al mal tiempo. Los tabúes alimenticios, por otro lado, se han mantenido en el tiempo, confirmando lo que, en muchos casos, podemos encontrar en la literatura (Emperaire, 1963, p. 238; Kuzmanich, 1980, p. 94; Tonko 2008, pp. 6, 15) acerca de no comer en la playa, no tirar las conchas vacías al mar, no comer los pulmones y riñones del lobo marino o las vísceras de la foca, entre otros, todo ello para evitar en cada caso situaciones indeseadas.

Por otro lado, la percepción de la higiene no queda muy bien parada al decir de los antiguos navegantes (de Córdoba, $1788^{14}$ ) o de los más recientes etnógrafos (Gusinde, 1991 [1974] ${ }^{15}$ ),

14 Trajo de regreso a bordo a cinco indios, cuya desnudez, estupidez $e$ insoportable hedor despertaron en nosotros al mismo tiempo horror y misericordia; se veía claramente que vivian en la más profunda miseria. Ninguna descripción puede pintar fielmente la verdad de la suciedad que provoca asco y el horroroso hedor que impera en estos hombres y en sus chozas, siempre llenas de los restos de su mesa. (Antonio de Córdoba 1788, cfr. Gusinde 1991 [1974], p. 198).

15 A los halakwulup no les falta un cierto sentido de higiene, aunque se encuentra en un grado bastante bajo. Aquel que se ha ensuciado mucho, trata en lo posible de limpiarse; especialmente cuando la suciedad cubre gran parte del cuerpo y se hace muy molesta; [...] El persistente olor a aceite de pescado y materias en tanto en lo que respecta al propio cuerpo como a los lugares de asentamiento que ocupan; aunque el descuido en esta materia y las costumbres poco aseadas a ojos de los europeos se justifican por una mayor preocupación hacia lo esencial de la propia supervivencia: la búsqueda de protección, abrigo o alimentos. Resulta, no obstante, significativas las apreciaciones peyorativas que se vierten sobre la apariencia externa, la visible suciedad o los olores nauseabundos a los que estaban habituadas las familias kawésqar, como una muestra del etnocentrismo que en mayor o menor grado se vertía desde el exterior.

Gusinde, (1991 [1974], pp. 200, 223) precisa que no hay ni un lavado diario o sistemático, ni una conciencia de que deba darse en todo el cuerpo, depende de la disposición y bienestar personal de cada uno, y con frecuencia basta con restregarse los ojos por la mañana para despegarse las legañas ${ }^{16}$. La mugre, secreciones cutáneas y el pestilente aceite de pescado son circunstancias que se alivian con la ventilación personal que implica moverse al aire libre, el roce en la piel de los duros vestidos de cuero que llevan y la casi diaria lluvia que limpia sus cuerpos. Era costumbre también en cualquier persona hacer una bola de musgo y frotarse ocasionalmente el cuerpo para lavarse o para secarse, y especialmente entre los hombres frotarse con tierra arcillosa muy seca para el lavado. A diferencia de los hombres que no les gustaba zambullirse en el mar, las mujeres se metían con frecuencia en el agua para mariscar o iban nadando hasta la canoa, por lo que, en consecuencia, sus cuerpos se mantenían más limpios.

Canclini (2007, p. 23) en su revisión bibliográfica coincide en que la suciedad y el mal olor son los dos aspectos negativos apreciados por

descomposición hace tiempo ha perdido su efecto sobre los nervios olfativos de los indigenas. (Gusinde, 1991 [1974], p. 199).

16 El descuido higiénico lo hace extensible a la choza, a la canoa y a los enseres que portan. Acostumbrados a la carne enmohecida, el mal olor dice no molestar a sus ocupantes, ni tampoco el de los desechos de moluscos que se esparcen alrededor de la vivienda, ya que el agua de lluvia lo aminoraba y el continuo cambio de lugar de residencia lo hacía más llevadero (Gusinde, 1991 [1974], p. 204).

En la actualidad, en Puerto Edén la basura se deposita en contenedores que un encargado municipal recoge y traslada a una isla próxima donde se deposita. Mientras que las aguas negras son canalizadas desde cada casa por una tubería hasta el mar. 
quienes conocieron en el pasado de cerca o de lejos a los indígenas de los canales. Hedor motivado al decir de unos y otros por el humo encerrado en sus chozas, la grasa de lobo marino o ballena con la que se untaban, o los parásitos que se reunían en la capa de mugre de la piel.

Con la introducción de ropas europeas se introdujo también el piojo, que provocó la molesta picazón y las escenas de despioje, sobre todo de los más pequeños (Ibid.: 201).

Sobre los cuidados del cabello, los relatos son diversos y a veces un tanto contradictorios, aunque hay que considerar siempre las diferencias existentes en razón al tiempo y al espacio. Emperaire (1963, p. 239) afirma que a los alacalufes con los que convivió no les gustaban los cabellos largos ni los llevaban como en el pasado, y aunque se los dejaran crecer durante las expediciones, luego se los cortaban nada más llegar a Puerto Edén. Antes de la introducción de las tijeras y los cuchillos se cortaban con conchas afiladas de choros, según cuentan Simón de Cordes y Sebal de Weert (159899, cfr. Emperaire, 1963, p. 144) que observaron cómo las mujeres se los recortan a la altura de las orejas, según la costumbre, y los hombres se los dejaban crecer sin más. Cabello que además de su aspecto estético contenía también una dimensión mágica al llevar asociada la creencia de poder operar algún tipo de maleficio sobre la persona a la que se le corta un mechón. Es por ello que la presumible víctima debía destruirlo cuanto antes arrojándolo al fuego (Ibid.: 240).

Gusinde por su parte, escribe que las mujeres en tiempos antiguos se dejaban crecer el pelo hasta los hombros y sujetarlo mediante un junquillo entrelazado a la altura de la frente. Las que él vio personalmente en la península Muñoz Gamero solían llevar el pelo suelto a la altura del cuello, con una raya en medio que dividía la cabellera en dos mitades irregulares y el flequillo sobre la frente (Gusinde, 1991 [1974], p. 201). La necesidad de desenredar y ordenar el pelo con el uso de un hueso de mandíbula de delfín con sus dientes, era más común en las mujeres que en los hombres (Ibid.: 203). Refiere también que los hombres de antes solían cortarse el cabello a 2 o $3 \mathrm{~cm}$. de largo para dejarlos crecer luego hasta el cuello, mientras que los más modernos se los cortaban regularmente a 1 o $2 \mathrm{~cm}$. y los dejan crecer tan solo unos centímetros más.

No deja de ser también llamativo el interés kawésqar por la depilación corporal, que entendemos tendría un sentido más estético que práctico para la adaptación ambiental. La depilación facial con el uso de conchas de choro a modo de pinza era una actividad a la que los hombres dedicaban una parte de su tiempo para parecer prácticamente lampiños, cuenta Emperaire (1963, p. 143). En tal sentido, Gusinde (1991 [1974], p. 203) refiere que la escasa vellosidad existente en brazos, piernas, cara, axila y partes pudendas, era arrancada con las propias uñas a modo de pinza, así como con conchas de moluscos, considerándose bello o agradable tener un rostro liso y sin pelo.

$\mathrm{Si}$ bien la higiene no se puede decir que mejoró con los primeros y sucesivos contactos esporádicos venidos del exterior, a la vista de los contagios de que fueron víctimas por los nuevos parásitos que recibieron, junto con las ropas; sí que experimentó una notable mejoría a partir de la convivencia estable junto a los colonos asentados en Puerto Edén y a las ayudas recibidas del Estado chileno, con los pro y contra que todo ello supuso: cambio a la vida sedentaria, consumo de alcohol, limitación de recursos marinos, pero al mismo tiempo mayor control higiénico y sanitario.

En cuanto al estado de salud, la investigación sobre restos arqueológicos (Aspillaga et al. 1999, pp. 132-134) muestra que las patologías de los antiguos canoeros cazadores recolectores de los canales patagónicos eran las propias del modo de vida que desempeñaban: otitis por el buceo en aguas frías, lesiones en muñecas, brazos, tibia y columna por la acción de remar, pérdida de dientes por el curtido de cueros y la cestería; lesiones todas ellas justificadas por las estrategias empleadas para subsistir en ese peculiar entorno marino, así como por el consecuente y adaptado desarrollo físico.

Los primeros contactos con navegantes y exploradores dio como resultado la introducción de enfermedades infecciosas desconocidas en el lugar hasta la fecha, y la inevitable muerte de parte de la población nativa por esos motivos, causas novedosas de muerte a las que habría que sumar las que fueron motivadas por la llegada de los loberos a la región. La estancia en la Misión de San Rafael, durante el tiempo que permaneció abierta desde 1887 hasta 1911, con la intención de proteger 
a la población fueguina de su extinción, fue todo un despropósito por la elevada tasa de mortandad producida debido a la tuberculosis, sífilis y demás enfermedades que allí mismo se contraían.

De acuerdo a los testimonios de Gusinde y Emperaire, así como a los de algunos kawésqar, en relación con lo vivido en el siglo XX, podemos deducir que han afrontado las enfermedades $y$ lesiones de un modo estoico, sin prestarle tampoco mucha atención al estado de salud, al igual que a la higiene. Han soportado sin queja y con resignación la presencia del dolor cuando ha tenido lugar, pero también han contado con procedimientos tradicionales para sanar distintas dolencias. Generalmente la aplicación de remedios naturales (calor, masaje, plantas medicinales, sangrías, etc.) han sido los más frecuente, a lo que hay que sumar las prácticas chamánicas, sobre todo en el pasado más lejano, para procurar igualmente alivio. Este último recurso, no obstante, implicaba por otro lado el temor de que fuera usado para dañar a alguien. Llama la atención, por ejemplo, la extendida preocupación por mantener el control sobre el corte del propio cabello o el de familiares y amigos, por miedo a las prácticas maléficas que alguien pudiera hacer con ellos.

Gusinde (1991 [1974, p. 425; 1951, pp. 153-157)] considera que el cuidado de la salud no era muy tenido en cuenta por los fueguinos $y$ era normal ver entre ellos a bastantes inválidos, personas raquíticas y debilitadas por la edad; y, aunque algunas personas podían superar los 90 años, también morían con frecuencia por causas accidentales a edades medias. Contra los problemas de salud, nos cuenta que respondían refugiándose en la choza en cuclillas junto al fuego; sin embargo, no parece que fuera la actitud resignada la norma a seguir ante la enfermedad a la vista de los numerosos remedios medicinales que cita. Para las erupciones cutáneas y eccemas se aplicaban aceite de pescado caliente; y en las fracturas de huesos se inmovilizaba durante meses la parte lesionada con dos o cuatro palos fuertes atados con tiras de cuero (Ibid.: 427). El aceite de lobo marino y otros pinnípedos tenía un uso muy generalizado, conservado como líquido espeso en bolsas; con él se untaban todo el cuerpo para protegerse del frío. El masaje sobre la parte afectada era utilizado para curar los resfriados, reúma y dolores musculares; en otras ocasiones aplicaban durante horas piedras calientes sobre las partes doloridas; beber una gran cantidad de aceite era usado como remedio para aliviar los dolores estomacales o intestinales. Para el dolor de cabeza la persona se acostaba en el interior de la choza al calor del fuego y permanecía quieta con la cabeza tapada. Para el dolor de oído se untaba aceite caliente con una pluma y se pincelaba el conducto auditivo. El dolor de estómago se remediaba bebiendo grandes cantidades de agua dulce, cubriendo el vientre y presionándolo con ambas manos. Para el dolor de ojos se restregaba el párpado inferior con un manojo de suaves plumas para hacer salir la pus, en su caso, y despejar el globo ocular. Del dolor de muelas no encontramos referencias, según Gusinde, poseen dientes sanos y fuerte, y nunca sufrieron de caries salvo en los últimos tiempos por los cambios habidos en la dieta. Para los enfriamientos se acostaba y cubría a la persona con dos o tres pesadas pieles, después de restregarle el cuerpo con aceite caliente, para que sintiera mucho calor (Ibid.: 530-532). Las incisiones realizadas con conchas de cholga durante meses eran igualmente frecuentes como método de sanación, al pensarse que en la sangre se concentran todas las materias nocivas, por eso hay que hacerla salir donde se junta. (Ibid.: 531). En cualquier caso, como señala:

En general nuestros fueguinos no gimen ni se lamentan con los dolores corporales o por estar enfermos, sino que se comportan silenciosos y calmos, incluso en medio del dolor más intenso; soportan los dolores más grandes y prolongados con completa resignación. (Ibid.: 532).

El chamanismo estaba presente también entre los kawésqar observados por Gusinde. El chamán pintaba todo su cuerpo de blanco y se colocaba una corona de plumas blancas de cormorán alrededor de la cabeza, a modo de diadema, siempre que ejercía tal función. Podían ser hombres o mujeres y, por lo general, su acción terapéutica consistía en arrodillarse junto al que recibía el tratamiento acuclillado en el suelo con el cuerpo erguido, y concentrar su atención en: soplar la parte del cuerpo dolorida, presionarle con la mano extendida, masajear, frotar con los dedos, 
chupar y escupir la sangre sustraída como causante del mal y escupirla fuera, todo ello acompañado de un canto ininterrumpido semejante a un ligero zumbido. Además, la actividad onírica también tenía presencia en el tratamiento, al soñar con el afectado para saber qué le ocurría y convocar en sueños a determinados agentes mitológicos: ballena, bandada de aves, cardumen de peces, etc., para que lo ayuden. El encargo terapéutico al chamán era compensado por adelantado con pieles de nutria, cuenta Gusinde, independientemente de los resultados del tratamiento; y no siempre su función era benéfica, dado que contaba igualmente con capacidad para dañar a las personas, sobre todo si estaba en posesión de un mechón de cabello de quien fuera a ser su víctima, mechón que podía maltratar para que tuviera un efecto maléfico sobre ella, de acuerdo al principio de magia simpatética (Ibid.: 527-529).

El temor a que el propio pelo o el de algún familiar o allegado cayera en manos de alguien que pudiera hacer mal uso de él y le produjera maleficios es destacado por Gusinde en base a su propia experiencia en la península Muñoz Gamero, al observar cómo los halakwulup se preocupaban por recoger por completo del suelo el pelo recién cortado a tijera por un peluquero para después hacerlo desaparecer, o cómo en alguna ocasión un hombre introducía su pelo cortado en la boca de su perro para que se lo tragara y así fuera destruido (Ibid.: 534). Temor que al parecer se ha mantenido durante siglos por lo que se puede leer de Fitz-Roy al decir:

Cuando uno de los oficiales cortó un mechón de cabellos a una mujer, los hombres se encolerizaron, y uno de ellos arrojó la mitad de él al fuego y enrolló la otra parte entre las palmas de su mano $y$ se lo tragó. Inmediatamente después, acercando las manos al fuego, como si las fuera a calentar, y mirando hacia arriba, dijo unas pocas palabras, aparentemente de invocación. (Ibid.: 533-534).

Emperaire (1963, pp. 105-108) como observaciones médicas manifiesta la existencia entre los kawésqar de un hígado hipertrofiado y trastornos orgánicos en más de la mitad de los sujetos auscultados: soplos diastólicos anormales, posibilidad de insuficiencia aórtica y de estrechamiento mitral en algunos casos. El ritmo cardiaco se apreciaba lento en los hombres: entre 45 y 58 pulsaciones por minuto la mitad de ellos y entre 60 y 70 la otra mitad; mientras que en las mujeres la mitad se mantenía entre 55 y 68 y la otra mitad entre 70 y 92 . Y la tensión arterial máxima en más de la mitad de los casos se situaba entre 11 y 12.5 .

Entre las enfermedades más comunes destaca la tuberculosis pulmonar, favorecida por el uso del alcohol y el tabaco, el sarampión y la sífilis (Ibid.: 108).

En cuanto al tratamiento de las lesiones y enfermedades contraídas, Emperaire refiere que cada cual se curaba sus propias heridas, las más leves espolvoreando cenizas en ellas, y las más severas aplicando una maceración en agua de plantas como la corteza del canelo o el tabaco, que se mantenían a modo de emplasto atado con una cinta de cuero en contacto con ella. Del mismo modo se procedía para luxaciones, torceduras, dolores reumáticos, rigideces de miembros, y todo aquello que en el lenguaje popular se traducía como sufrir de huesos. Para los males de vientre se aplicaba sobre el abdomen una pasta caliente de ortigas molidas (Ibid.: 242-243). Cita también en su tiempo la existencia de algunos curanderos que sin tener ningún tipo de privilegios ejercían su función tratando de eliminar las enfermedades más graves y dolorosas que implicaran fiebre, debilidad o el abatimiento de la persona. En tal sentido procuraban sacar fuera el mal interno, practicando en las partes doloridas del afectado incisiones sobre las que succionar la sangre que mana, para depositarla seguidamente en una concha, dejarla coagular junto al fuego y colocarla bajo la cama de ramas del enfermo hasta que éste sanara.

La sangre que fluye de cada incisión se aspira por la boca, largamente $y$ con fuerza. El operador permanece largos minutos inmóvil, con los labios oprimiendo la piel del paciente. Se echa la sangre enferma en una concha. [...] Una vez llena, la concha es depositada sobre las cenizas calientes cerca del fuego, y cuando la sangre se coagula y comienza 
a calcinarse, se la coloca bajo la cama del enfermo. (Ibid.: 243-244).

Kuzmanich (1980, p. 103) indica que eran las mujeres quienes ejercían el papel de curanderas, empleando los tradicionales métodos de incisiones en la piel, succiones, masajes e incluso abluciones en el mar.

Ya en el siglo XXI el estado de salud de la población kawésqar de Puerto Edén, como nos contaba Rodrigo Esteban Díaz Rivera, enfermero responsable de la posta de atención primaria existente allí, no difiere de manera significativa del resto de colonos residentes en ese lugar: hipertensión, colesterol, diabetes, resfríos, afecciones gastrointestinales, dolores de espalda, daños hepáticos, etc. Problemas derivados del modo de vida que desarrollan en ese espacio geográfico, pero todos ellos prevenibles y controlables mediante la posta de atención primaria para promover la salud, y la posibilidad de evacuación en helicóptero a través del Servicio de Salud de Magallanes en caso de extrema urgencia.

En otro orden de cosas, sobre las relaciones sexuales nos cuenta Emperaire (1963, pp. 224-227) que empezaban pronto, situaba el promedio de edad del matrimonio en 13 o 14 años para la mujer y 15 o 16 para los varones, no estando permitidas las uniones entre parientes próximos, ya fuera por vía paterna o materna. Ese promedio estima Gabriela Paterito que debía ser algo mayor, sobre los 20 años. Alberto Achacaz, por su parte, confirma que los flirteos amorosos eran muy comunes también en su juventud, donde se las ingeniaban para llevarse a las mujeres al monte (cfr. Vega, 1995, p. 75-87).

Si bien Gusinde (1991 [1974], p. 345) afirma que en la península Muñoz Gamero la monogamia era la forma matrimonial más extendida, otros autores como Calvi, Krickeberg, Bird, Emperaire o Cooper (cfr. Gusinde, 1991 [1974], pp. 347349) confirman la poligamia como la práctica predominante en el pasado si la situación lo permitía.

La pintura corporal estaba presente en la ceremonia matrimonial como distintivo del novio y la novia, así como el comensalismo en su celebración. Llama la atención la actitud de respeto del yerno hacia el suegro, expresada corporalmente al evitar mirarlo fijamente a la cara, sentarse frente a él, o dirigirle la palabra, si no era a través de su hija en los primeros años (Gusinde, 1951, p. 243; 1991 [1974], pp. 350-353). Así como el pudor que dice Gusinde (1991 [1974], p. 453) mostraba la mujer al tapar sus genitales cuando se sentaba en el interior de la choza con su marido, espacio privado en donde únicamente tenían lugar las caricias.

Las reacciones ante el adulterio eran al parecer desproporcionadas en la comparación de géneros, según se desprende de lo registrado por Gusinde, ya que la mujer se limitaba a reprochar de palabra a su marido la infidelidad, mientras que el hombre le propinaba una paliza a ella y en ocasiones a su amante. Aunque ella, pese al dominio masculino, podía tomar la iniciativa de la separación en caso necesario. La soltería en la mujer a partir de cierta edad o la viudez prolongada no parece que fueran situaciones frecuentes (Ibid.: 354-358), como asegura también Gabriela Paterito, aunque sí se daban en los hombres.

Tanto Alberto Achacaz (cfr. Vega, 1995, pp. 87-88) como Gabriela Paterito en conversación personal, confirman que los criterios de belleza, o más concretamente los criterios que motivaban la atracción para elegir pareja se fijaban más en los valores personales que en los atributos físicos, atributos funcionales más que estéticos ligados con la capacidad de subsistencia: a Achacaz le gustaba la mujer gruesa que le diera calor, y a Paterito el hombre trabajador.

El número de hijos por familia ha sido muy variable en las últimas generaciones, las parejas con 8 o 10 hijos contrastan con las que no dejaron descendencia; sin embargo, de los posibles procedimientos anticonceptivos no encontramos referencias del pasado, ni tampoco eran conocidos para Gabriela Paterito que jamás recurrió a ninguno. Igual ocurre con el desconocimiento de posibles casos de homosexualidad en hombres o mujeres, de lo que al menos no se habla.

\section{ACTIVIDADES LÚDICAS, EXPRESIVAS Y MOTRICIDAD COTIDIANA}

En la observación de la vida cotidiana el comportamiento lúdico, a juicio de Emperaire (1963, pp. 221-222), era austero; aunque, como indica también Gusinde (1991 [1974], p. 582) es 
a través del juego como el niño se hace adulto y aprende de un modo lúdico las tareas de las que más adelante será responsable. Entre los juegos y/o distracciones observadas por estos autores entre los niños y niñas destacan los que tienen un carácter motriz y de imitación como: fabricar a tamaño reducido los utensilios habituales empleados por los adultos en sus quehaceres (arpones, $\operatorname{arcos} y$ flechas en miniatura o canoas); hacer navegar las pequeñas embarcaciones de corteza; construir las niñas pequeñas cabañas con fuego en su interior para cocer marisco, mientras los niños se dedican a cazar roedores o pájaros a pedradas, repartiendo así las tareas al modo que hacen los mayores; hacer girar una anilla sobre el dedo; lanzar pequeños arpones sobre montones de tierra o sobre raíces de lampazo; bajar corriendo la pendiente de un talud, rodar sobre una pendiente, o simplemente pasear en grupo por la playa; columpiarse; y luchar con otro para procurar tumbarlo, ante la diversión de la gente mayor. Entre los adultos, por su parte, destaca el juego de atar y desatar con rapidez la canoa representada por un dedo a un poste de la choza; el juego de pelota (hecha con la guata o estomago del lobo marino) golpeada con la mano, del que también participaban los niños; y ocasionalmente la lucha cuerpo a cuerpo hasta tumbar al contrario en el suelo ${ }^{17}$.

Gabriela Paterito también manifiesta que se jugaba poco en su niñez, y menciona como más frecuentes el juego de puntería de los chicos al disparar arpones contra determinados objetos amontonadas en el suelo que simulaban el lobo marino; el juego con la guata hinchada que compartía con más personas, niños y mayores, en el interior de la carpa; así como hacer carpitas pequeñas $e$ imitar las tareas de los mayores. Francisco Arroyo por su parte señala que niños y niñas jugaban habitualmente a los mismos juegos por separado, aunque en algunos se mezclaban; destacando el lanzamiento de piedras con honda o voleadora como ejercicio de puntería de los jóvenes. Alberto Achacaz, de acuerdo a su experiencia, señala sobre todo el juego de pelota como la actividad lúdica principal. Todos esos juegos son confirmados igualmente por el kawésqar Carlos Renchi en sus

17 Las peleas no eran ni son frecuentes entre los kawésqar, sin embargo, Alberto Achacaz informa de cómo se resolvían las disputas entre los mayores cuando se llegaba al relatos (Peralta, 1993, pp. 289-290).

En cuanto a la danza, como actividad expresiva, además de las ejecutadas con motivo del kálakai con pintura corporal incluida, Gusinde (1991 [1974], pp. 562-565) hace referencia a un buen número de variantes practicadas por hombres y mujeres adultas, generalmente en el interior de grandes chozas. De ese modo, nos describe cómo en ocasiones hombres y mujeres unidos por las manos o por los hombros se desplazan de manera rítmica de lado a lado y adelante y atrás. Dos mujeres dentro de un círculo de espectadores acuclillados avanzan y retroceden lentamente con pasos cortos hasta que son reemplazadas por otra pareja de mujeres que ocupa ese lugar. Dos mujeres colocadas frente a frente mirándose a la cara se mueven rítmica y simultáneamente a un lado y otro; o dos parejas de mujeres se desplazan un par hacia adelante y el otro hacia atrás. Cuatro mujeres en línea lateral sujetas de las manos rodean el fuego. O imitaciones de diversos animales (lobo marino, ballena, zorro, nutria, distintas aves, etc.) con gestoformas alusivas a los mismos, todo ello acompañado de canto. Entendiendo que se trata de un baile ritual, o en ese contexto.

Canto que, como indica María Ester Grebe (1974, pp. 17-19), además de los juegos cantados alacalufes encontrados en Puerto Edén entre 1959 y 1971 (jugando con el mar, jugando redondo -kenajanayowa-, columpio -karaktúe-, haciendo fuego -wajena-), se pueden distinguir unido a la danza en un doble repertorio: uno religioso, ya desaparecido, ligado a ceremonias rituales (ritos mortuorios e iniciáticos); y otro profano, aún vigente, ligado a las actividades cotidianas y sentimientos humanos (tareas laborales y expresión del contacto e interacción con la naturaleza y la flora y fauna de los archipiélagos).

En cuanto a la motricidad cotidiana, Gusinde (1991 [1974], p. 335) observa que tanto los hombres como las mujeres inclinan el cuerpo hacia adelante en posición erguida, aunque mantienen bien la estabilidad en parado y al caminar, mostrando una notable movilidad corporal y, sobre todo, una asombrosa agilidad en todos sus miembros, incluso en las personas con avanzada

enfrentamiento físico y cómo él mismo aprendió la técnica de lucha (cfr. Vega 1995, pp. 55-56, 82-83). 
edad (Gusinde, 1951, p. 47). La forma de caminar posee rasgos distintivos con pasos cortos, poca elevación de la pierna y desplazamiento del pie casi horizontal, que da la impresión de inseguridad y avance lento, pesado e irregular (Gusinde, 1991 [1974], p. 156).

El prolongado letargo en la choza, con más de 12 horas de promedio, motivado con frecuencia por las malas condiciones climáticas, es a juicio de Gusinde un factor condicionante de esa peculiar forma de caminar, aunque la mantenida inactividad se conjugaba con momentos o periodos de mucha acción en donde se ponía a prueba la fuerza y resistencia de hombres y mujeres (Gusinde, 1991 [1974], pp. 154-155). Circunstancia que es corroborada y vivida personalmente por Gabriela Paterito, al señalar que los desplazamientos por los canales se realiza en canoa y por tanto se camina poco, observando al mismo tiempo, junto con Alberto Achacaz (cfr. Vega, 1995, pp. 100-102), la prudencia con la que hay que desenvolverse por esos lugares para no poner en peligro la supervivencia. Francisco Arroyo afirmaba por su parte que dentro de la choza el descanso y la conversación se producía en cuclillas, sentado o recostado sobre las ramas que hacían de colchón, al igual que afirma Gusinde (1991 [1974], p. 156).

La resistencia al frío se aprecia como un hecho muy significativo, por lo menos hasta el primer cuarto del siglo XX, a la luz de las fotos que aparecen de niños completamente desnudos en los canales (Gusinde 1991 [1974], Apéndice). La resistencia al frío como consecuencia de la adaptación a su entorno ambiental es más destacada en las mujeres que en los hombres a juicio de Cárdenas et al. (1993, p. 68) y Alberto Achacaz (cfr. Vega, 1995, pp. 23-24). Aunque tanto Gabriela Paterito como Francisco Arroyo coinciden en afirmar que las mujeres y los hombres buceaban a pulmón en las aguas gélidas para encontrar marisco. Tanto una como otro nos cuentan su experiencia de buceo en las gélidas aguas, experiencia que se mantiene en la actualidad aunque con el uso de trajes de neopreno que la hacen mucho más fácil a la del pasado.

To buceaban la tre' o cuatro mujere que haiga, to unido, to junto, y esa persona que buceaba tenía que tener buen fuego para despué', cuando llegue, que se calore, porque el agua está helao helao, (¿el hombre nadaba y buceaba igual que la mujer?) sí to, to saben nadar, sabe bucear igual, cuando tiempo verano se sacaba marisco hombre, buceaba sí, hay alguno hombre [...], porque a bucear e' a puro pulmón, no con compresor o con el buzo, na así na má, puro pulmón, y cuesta así, cuesta de sacar marisco, (¿cómo se llevaba el canasto?) se lo mordía y entonce ahí lo iba sacando lo iba poniendo, el canasto lo llevaba mordio, no ve que canasto tiene asa pa garrar, ya entonce lo deja abajo y lo va llenando con marisco, con cholga, cuando llena si sacaba. (Entrevista a Gabriela Paterito, 27 de noviembre de 2008).

En contraste con la versión de Gusinde (1951, pp. 202-203) acerca de la práctica de la natación en mujeres pero no en hombres, Alberto Achacaz informa de cómo niños y niñas aprendían a nadar en tiempo de verano

Los kawéskar, hombres y mujeres, sabíamos nadar (lales). Los niños también aprendían. Se comenzaba en la orilla del mar, de a poco, avanzando hasta llegar a lo profundo. Nadábamos moviendo los brazos hacia delante y los pies hacia los costados.

En el tiempo de calor [...] ahí aprendiamos. [...] Nadábamos cortito, moviendo los brazos abajo, a lo perrito como dicen ustedes, y pataleando [...] ¡Puta, así nadábamos como siete, cinco, seis metros de largo! Las mujeres también lo hacian. (cfr. Vega 1995, pp. 23-24).

Gabriela Paterito dice también que el trabajo de remar en la canoa monóxila (de tronco hueco) lo podía realizar cualquiera, no siendo tarea propia de la mujer como se cuenta en la literatura (Fitz-Roy, cfr. Cárdenas et al. 1993, p. 74; Lautaro Navarro, cfr. Vega \& Grendy, 2002, p. 37; Coiazzi, 1914, p. 111; Agostini, 1941, p. 65; Gusinde, 1991 [1974], p. 244; Emperaire, 1963, p. 163; Kuzmanich 1980, p. 93; Chapman, 2002, p. 18; Manzo, 2002, p. 150). Navegación a remo que a veces se implementaba con el uso de una vela. 
Todo, cualquiera podía remar, hasta los niño, la mujer, niño, todo. Yo aprendi remar chiquitita porque lo'xigía, claro, uno no sabe remar póngale sale remar sola y la lleva el viento y pierde, para eso lo enseñaba a remar.

Siempre ese era mejor má' estable andar trayendo esa vela, cuando e viento como e' a favor yo pueo salir de acá pongo vela que hasta dónde pueo llegar la hora del día, si el día e largo hasta que oscurezca, asi se usaba, [...] estando vela canoa anda pura vela, nada má, ahora si hay calma no hay viento se rema, [...] la mitad de la canoa lo' do', sí, ahí etá lo' do' el banco acá y entonce son do' persona o tre' persona en vece cuando hay canoa má' grande. (Entrevista a Gabriela Paterito, 26 de noviembre de 2008).

Sobre el desarrollo de los sentidos corporales, Gusinde (1991, [1974], p. 156) observa que tenían una notable agudeza visual y auditiva, aunque no olfativa por los malos olores que, según él, soportaban; siendo la vista afectada por el constante humo que se hallaba presente en la vida tradicional, como nos confirmaba también Gabriela Paterito.

En cuanto a la gestualidad, de acuerdo con Odone y Mege (cfr. Alvarado, 2007, pp. 37-48), llama la atención las poses y expresiones que en las fotografías tomadas de los fueguinos en la misión de la isla Dawson, entre 1889 y 1911, dan la impresión de estar desubicados, ordenados y alineados por edad y sexo, con el rostro serio y mirada triste, al encontrarse recogidos fuera del lugar habitual de residencia y no realizar sus tareas normales, por lo que evocan más bien estampas del proceso civilizatorio y no de su vida cotidiana en los canales. Pierre Auger (1958, cfr. Barros \& Armstrong, 1975, p. 5) observa el carácter reservado o retraído de los kawésqar a la hora de tomar la iniciativa de la acción ante otra persona. Sin embargo, distintos autores coinciden en afirmar la gran cualidad mímica e imitadora de los kawésqar. Observaba Essendorfer (cfr. Gusinde, 1991 [1974], p. 548): "La mímica y el movimiento de los ojos eran activos, la expresión del rostro no era en absoluto carente de inteligencia, aunque medrosa e intimidada". Emperaire (1963, pp. 218-221) decía por su parte que "Los alacalufes sobresalen en la imitación de las actitudes de todos los animales." Especialmente manifestaban su destreza al imitar el canto de distintos animales como el zorro, el carancho (ave rapaz), la nutria, el pingüino, la foca, la rata, la araña, el ganso, etc., acompañado de la danza.

Esta imitación de los animales forma el tema de la mayoría de sus cantos, que son pantomimas completas, pues no sólo se representan las actitudes por los movimientos correspondientes del cuerpo del actor, sino, además, por la descripción de esas actitudes que forman el texto de cada canto y que son subrayadas por la modulación de canto apropiada.

El cantor, que agacha la cabeza, simula el pico del pájaro poniéndose la mano extendida a la altura de la boca, imitando el movimiento de cabeza del fil-fil en cada uno de sus pasos. [...] En los cantos mimados se insertan también el canto y la danza de las piedras de fuego. El danzarín, sujetando en las manos sus dos piedras las golpea una contra otra, puntuando cada sílaba con la percusión de las piedras y el movimiento de sus pies: 'Yo danzo firme (lanzo lejos mis piernas) para que tú me des el fuego'. (ibid.: 218-221).

Según el lingüista Christos Clairis (cfr. VV.AA. 1976, pp. 43, 87) emitían sonidos peculiares con el uso de la garganta, la lengua y los labios, y sus ademanes acompañaban lo que de palabra decían. Imitaban el canto y el vuelo de las aves, el movimiento de los lobos marinos, o la forma de hablar de la gente. Observa, no obstante, que en la actualidad permanecen totalmente inmóviles mientras entonan cantos.

Gabriela Paterito nos decía, sin embargo, que en la actualidad pocos kawésqar saben imitar con maestría los sonidos de los animales en la caza; y tanto ella como Francisco Arroyo afirmaban que el uso complementario de las manos cuando se habla es cosa de "los blancos" no de kawésqar; como en efecto pudimos apreciar personalmente en la interacción. No no hay, no no no, no se usa eso (gesticular con las manos), no, sin mover, no nunca, porque ese modo son una persona 
chileno, este blanco que e', pero nosotro kawésqar la gente antigua nunca, decía Gabriela.

La actitud silenciosa del kawésqar a la que hace referencia la literatura (Gusinde, 1991 [1974], pp. 398-401), Gabriela Paterito nos dice que se mantenía en la caza pero no en otras circunstancias, como en las travesías en canoa.

Sí conversa, ¿dónde vamo pasar? se preguntan uno con otro o ¿dónde vamo pasá mariscar?, se conversa entre ello, o ¿dónde parte vamo ir?, se conversa to esa cosa, to esa cosa se conversa entre ello, no puede andar callao, [...] cuando estaba cazando, ahí sí, cuando hay una cosa pa cazar que está cerca uno no puee ni conversá po, pero si está sola ahora llega a un campamento, do' campamento que haiga, entonce se lo invitao uno con otro, vamo sali mariscar o vamo ir tal parte, ese era su modo que tenía pero la cosa e' que esa persona no e' una persona extraño e pura familia, una pura familia que andaba, to que andaba era pura familia" (Entrevista a Gabriela Paterito, 26 de noviembre de 2008).

Gusinde, 1991 [1974], p. 424) observa los efusivos abrazos que se dan como muestra de mutua simpatía, y destaca por otro lado la conducta silenciosa, estoica y pacífica, aún en los momentos más dolorosos:

No se oyen quejas ni gemidos lacrimosos, sólo rara vez un tenue murmullo, cuando los aqueja un gran dolor persistente; callados soportan todo padecimiento. [...] dejan que sucedan muchos males, sin pensar en venganza o desquite. [...] Extrañamente, en la disputa de dos mujeres no se mezcla ningún otro adulto, y dejan que las contrincantes, por sí solas, apaguen su ira; éstas no chillan ni gritan, sino que reciben en silencio los dolorosos golpes. (Ibid.: 575).

El dolor lo expresan, dice: "desfigurando la cara en gran aflicción" y haciéndose eco de algunos testimonios históricos sobre el carácter expresivo kawésqar recoge lo dicho por Coppinger y Skottsberg:

(Dice Coppinger) Algunas de las emociones son expresadas por muy manifiestas contorsiones de las coyunturas y piernas. El deleite, cuando es intenso, se manifiesta exhibiendo los dientes apretados, acompañado por un sonido chasqueante y un curioso movimiento de meneo de arriba abajo. La ansiedad es expresada con un sonido chasqueante y espumarajos. La ira la muestran apretando el labio superior, alargando la quijada inferior o mandíbula, y con una ligera exhibición de los incisivos superiores. (Ibid.: 576).

(Dice Skottsberg) Predomina en el grupo una vida silenciosa, que no implica necesariamente la tristeza. Simplemente las manifestaciones exteriores de alegría o de contento, así como las de dolor, siempre son ponderadas.

$\mathrm{Su}$ indole completamente silenciosa, incluso en el juego no hacen ruido $y$ desconocen por entero un comportamiento gritón, son tímidos, incluso frente a sus propios congéneres; en todas sus peticiones se muestran suplicantes. ${ }^{18}$ (Ibid.: 578, 582).

\section{REFLEXIONES FINALES}

Llegamos al final del recorrido por la corporeidad kawésqar y es el momento de recapitular, hacer balance y aportar unas últimas consideraciones.

La primera surge de las diferencias observadas en la descripción de ciertos comportamientos corporales y motrices a través de la literatura, en las que es preciso considerar la fecha y el lugar en la que están referidas. El trabajo de campo de Gusinde, por ejemplo, fue realizado con los kawésqar de la península Muñoz Gamero unos 30 años antes (aunque se publicara mucho después) al de Emperaire que trabajó en el entorno de Puerto
18 Descripciones de actitudes y de estados de ánimo, no obstante, que podrían también estar contaminadas por el observador. 
Edén, a unos $400 \mathrm{~km}$. más al norte que el anterior. Diferencias que se ven en algunos casos más acusadas si comparamos las versiones ofrecidas por navegantes, exploradores o misioneros en momentos históricos muy distantes, con el amplio territorio marítimo comprendido ${ }^{19}$ y las numerosas influencias recibidas de agentes externos. Pero en cualquier caso, aún refiriéndose al mismo tiempo histórico, es necesario tener en cuenta un cierto margen de diversidad interna en todo grupo étnico y no es ésta una excepción, diversidad en ciertas maneras de proceder, de actuar con el cuerpo, por las que se enriquece el acervo cultural en su conjunto y sirve entre sí como signo de distinción, ya que no todos son igualitos.

Diferencias que hemos tenido ocasión de observar también en razón a la edad y al género, en las tereas desempeñadas por niños, jóvenes y adultos, por hombres y mujeres, sobre todo en aspectos pragmáticos relacionados con las técnicas de subsistencia en la vida cotidiana, así como en la diferente consideración social y en los aspectos simbólicos ligados a los rituales de iniciación, ya desaparecidos.

Pero además de las diferencias, son más notables aún las semejanzas mantenidas en su proceso histórico, desde los primeros contactos con los miembros de la expedición española de Jofré de Loaysa en 1526 hasta aproximadamente el primer tercio e incluso mediados del siglo XX, en la que tuvo lugar una transformación decisiva hacia la vida sedentaria. De entre todas las similitudes, encontramos al menos tres destacados hechos que se han mantenido constantes y, con matices, aún persisten en la actualidad, se trata de: la forma de desplazamiento por los canales motivada por la necesidad o el deseo de cambiar regularmente de residencia; la dependencia del marisco como producto alimenticio; y la práctica estacional de la caza del lobo de mar. Tres hábitos bien instalados en la mentalidad kawésqar, existente todavía entre la población mayor residente en Puerto Edén, que

19 Los kawésqar del norte tenían comportamientos diferentes a los llamados tawokser.

20 El Estado autoriza la captura de hasta 60 animales juveniles al año con independencia de la época del año en que lo hagan. La resolución además, apela al derecho ancestral que les asiste y reconoce en ello el derecho de usar las artes tradicionales de caza. En la actualidad no se caza el lobo han moldeado un tipo de cuerpo marcado por la navegación a remo (sustituida en los últimos tiempos por el motor fuera borda), el regular consumo de marisco, especialmente de cholgas, y la vivencia como cazador marino ${ }^{20}$ que constituyen tres importantes señas de identidad.

El cuerpo kawésqar a través de las diversas contingencias referidas (parto, primeros cuidados, rituales de iniciación, vestuario, alimentación, salud, sexualidad, juegos, danzas, gestualidad, etc.) nos ha desvelado las distintas formas de producción cultural y relación social; el cuerpo con su envoltura y en movimiento nos ha hecho entender las estrechas relaciones con el entorno ambiental donde viven, la tecnología al uso, las maneras de ganarse la vida, de interactuar con los demás, de entender el mundo; y, cómo no, ha sido un buen indicador para valorar el proceso de cambio, ya que, como decía Merleau-Ponty (1966), la existencia depende de la manera en que encarnamos la experiencia que vivimos. Nos ha permitido ver que todo lo que va perdiendo función se transforma o desaparece con la llegada de nuevos tiempos, como ocurrió con el kalakai y el yenchiháwa, o con el uso de la canoa de corteza y la monóxila; que la convivencia con otras gentes, la apertura a nuevos modos de vida trae consigo ventajas e inconvenientes, que el progreso y la incorporación a un mundo más global trae consigo renuncias y hace que los cuerpos se resientan, a veces de manera catastrófica por lo sensibles que son.

Comenzamos este trabajo hablando del nacimiento, de la venida al mundo de un nuevo cuerpo, de un nuevo ser humano kawésqar, y queda pendiente dedicar al menos algunas palabras a su despedida y desaparición. Son numerosos los testimonios encontrados en la literatura que hablan de las prácticas mortuorias, prácticas que señalan distintos procedimientos de inhumación según los autores: sumergido en el mar lejos de la orilla, tras ser envuelto en pieles de foca con grandes piedras atadas (Emperaire, 1963, p. 253; Clairis, cfr.

de mar con arpón, a la antigua usanza, pero en torno a la primera quincena de enero los kawésqar se dirigen a las parideras para capturar las crías (popis) a garrotazos, sin superar la cuota permitida. No obstante, acostumbrados ya a la navegación con motor fuera borda, el problema surge por la dificultad para conseguir combustible suficiente que les permita emprender el viaje de ida y vuelta. 
VV.AA. 1976, p. 78); colocado en el interior de una pequeña choza sujeto con estacas y previamente envuelto en una piel de lobo o foca cosida, con el cuerpo agrupado en cuclillas (Emperaire, 1963, p. 252; Gusinde, 1951, p. 332); enterrado en un hoyo en posición horizontal, envuelto en piel de lobo y tapado con ramas y piedras (Gusínde, 1991 [1976], p. 458); depositado en un roquedo o lugar seco siempre envuelto en piel (Achacaz, cfr. Vega, 1995, p. 67; testimonios orales de Gabriela Paterito y Francisco Arroyo, 2009); en el interior de cavernas (Debbene, cfr. Gusinde, 1991 [1976], p. 460); en el interior del bosque envuelto en pieles (Fitz-Roy, cfr. Gusinde, 1991 [1976], p. 461). Unos apuntan que eran abandonados junto a todas sus pertenencias (Achacaz, cfr. Vega, 1995, p. 67); mientras que otros hablan de la destrucción total de las mismas para evitar que su espíritu merodee por el lugar y moleste a los vivos ${ }^{21}$ (Emperaire, 1963, p. 254; Gusinde, 1991 [1976], p. 463). No obstante, se dan bastantes coincidencias en la tristeza y expresiones de dolor ${ }^{22}$ manifestadas tras la pérdida de un ser querido, en las pinturas de fondo negro con las que dibujan el rostro y cubren distintas partes del cuerpo como expresión de luto en el velatorio y días sucesivos; y en un cierto temor hacia los fallecidos, motivo por el cual mantenían generalmente las distancias con los lugares de enterramiento.

En cuanto al más allá de la muerte, aunque los testimonios orales que registramos de Gabriela Paterito y de Francisco Arroyo insisten en que con la muerte "todo se acaba, no hay nada más", y en la inexistencia de una posible alma que trascienda al cuerpo, las versiones de otros investigadores como José Tonko (hijo mayor de Dña. Gabriela) y Oscar Aguilera sobre los testimonios de estos mismos kawésqar apuntan en una dirección bien distinta. En los abundantes relatos mitológicos registrados por Aguilera (1997) sobre el tema de la muerte, ésta se produce no por enfermedad, como suele acontecer en la vida real sino por motivos tales como rompimiento de tabúes, engaños, venganzas, por criaturas monstruosas, por conflicto con grupos antagónicos, transformación en

21 Cuestión dudosa planteada por Emperaire, que tal vez tenga que ver más bien con un Tabú.

22 Gusinde (1991 [1976], p. 463) señala el corte de pelo, al igual que la pintura negra facial, como expresión de luto, y las incisiones sangrantes de varios centímetros en los antebrazos cuando la pérdida sufrida provoca un intenso animales, o congelación, entre otras; muertes todas o casi todas ellas nada apacibles. Y es el sueño, al igual que ocurre en otros pueblos amerindios, lo que vincula el mundo real con el mundo mítico, como expresa Aguilera:

Los espíritus de los muertos, que se convierten en auxiliares de los vivos en situaciones extremas, se comunican con estos últimos a través del sueño. Este es el único vehículo, la única vía de comunicación con el mundo de los vivos, ya que la persona al perder la corporalidad con la muerte, sólo puede comunicarse por una vía que excluye el contacto físico. Al respecto, hay que señalar que los kawésqar hacen la distinción entre lo que correspondería al alma (os) y una fuerza vital que mueve al cuerpo (aksæmhar).

La muerte ocasiona que la fuerza vital abandone el cuerpo, con lo cual el alma también se separa de la énvoltura física. Para el vivo, la fuerza vital muere, pero en la muerte sigue funcionando en conexión con el alma. La fuerza vital que movía al cuerpo en vida hace que el alma 'viva', se mueva y actúe en el mundo de la muerte (Ibid.: 21).

Interesante información proporcionada por los informantes ${ }^{23}$ de Aguilera sobre el tema de la muerte, el cuerpo, el "alma" (os) y la "fuerza motriz" (aksǽmhar), en línea con lo que Tonko afirma acerca del más allá y la concepción de la persona:

Sí existe más allá, más allá del océano Pacífico, donde se junta la mar, el cielo, la vista se pierde en el horizonte, y por ahi se esconde el sol, y de hecho en la cultura kawésqar el sol camina, es movible, tiene patas, por eso se dice él sol se va'se va caminando por ahí y sale caminando, se dice

dolor entre los deudos.

23 Los datos provienen de los informantes José Tonko Wide (Kstákso), Virgilio Renchi Sotomayor (Táltok) y Carlos Renchi Sotomayor (C'ákuol), en entrevista realizada el 6 de febrero de 1984 en Puerto Edén y grabada (Archivo sonoro: T-DIA-PE-060284B=9). 
en la cultura kawésqar. Existe concepción de la muerte, existe el más allá [...] existen dos mundos en la cultura kawésqar, un mundo concreto, donde estamos nosotros conversando, y otro mundo invisible en el más allá que podría estar aquí en este momento pero en otra dimensión. Cuando la persona muere se va a ese mundo, el mundo de lo natural de lo inmaterial, no sé cómo llamarlo y allá los vivos no podemos entrar, solo se puede entrar una vez muerto, y la vida allá no es edén, como se califica en la cultura occidental, sino que es una copia fiel de la realidad del mundo concreto, entonces cuando se muere la gente vuelve a llevar los mismos problemas, la misma vida que aquí, este mismo mundo se traspasa al más allá, ahora el único ser que puede transitar entre esos dos mundos es el Yeksólok o la Ayayema ${ }^{24}$.

En la concepción kawésqar en términos teóricos existen tres estados, estadios o entes, uno es la carcasa, el otro es el espíritu, y el otro es la llama que podia estar encendida, o fuerza vital o motor que mueve; entonces, cuando viene Ayayema al campamento se va el espíritu pero no la fuerza vital todavía, después de tres o cuatro meses se apaga esta llama $y$ ahi se muere la gente, entonces el ser humano es energía y además compuesto por estos tres elementos. (Entrevista a José Tonko, 16 de noviembre de 2008).

Pero volviendo al más acá, a la realidad contingente en la que, como dice Elias (1987, p. 123), la mutabilidad natural del hombre es una constante y nada permanece invariable para siempre, nos encontramos con la memoria como herramienta para reconstruir los pasados kawésqar a través del rastro que dejaron sus cuerpos, cuerpos socializados que fueron testigos y gestores de diferentes momentos históricos, cuerpos que han hecho valer una vez más la enorme capacidad adaptativa de los seres humanos, esta vez como canoeros nómadas en una de las regiones más

24 Espíritu que transita por los dos mundos y tiene un carácter perturbador al intervenir y modificar el orden difíciles del planeta para la supervivencia. Pero lejos de terminar con una visión nostálgica por aquello que fue y no volverá, con el reconocimiento de los valores culturales de los antepasados que, pese a las dificultades, resistieron generación tras generación permitiendo la continuidad de su pueblo, aún quedan muchas páginas por escribir sobre él porque hay presente y habrá futuro. Historias por venir que, como siempre, producirán y quedarán registradas en sus cuerpos, transformados o reinventados de acuerdo a los anhelos y desafíos de los nuevos tiempos, en los que habrá que ver qué peso tendrá la memoria en el diseño de la realidad y la construcción de la identidad.

\section{BIBLIOGRAFÍA}

Aguilera, O. E. (1997). El Tema de la Muerte en la Literatura Oral Kawésqar (Alacalufe). Anales de la Universidad de Chile. Sexta Serie, 6, 13-40.

Agostini, A. M. de (1941). Andes Patagónicos. Viajes de exploración a la cordillera patagónica austral. Buenos Aires: Edición propia.

Alvarado, M. (2007). Fueguinos. Fotografías siglos XIX y XX. Imágenes e imaginarios del fin del mundo. Santiago de Chile: Pehuén Editores.

Aspillaga, E., Ocampo, C., \& Rivas, P. (1999). Restos óseos humanos de contextos arqueológicos del área de isla Navarino: indicadores de estilos de vida en indígenas canoeros. Anales del Instituto de la Patagonia, 36, 123-135.

Aylwin, J. (1995). Comunidades indígenas de los canales australes: antecedentes históricos y situación actual. Santiago de Chile: CONADI

Barros, A., \& Armstrong, E. (1975). Aborígenes Australes de América. Santiago de Chile: Editorial Lord Cochrane.

Baudrillard, J. (1974). La société de consommation. Ses mythes, ses structures. Paris: Gallimard.

Birdwistell, R. (1952). Introduction to Kinesics. Louisville: University of Louisville Press.

Bourdieu, P. (1988). La distinción. Criterio y bases sociales del gusto. Madrid: Taurus.

(1991). El sentido práctico. Madrid: Taurus.

Brohm, J. M. (1982). Sociología política del deporte. México: Fondo de Cultura Económica.

Canclini, A. (2007) (2 ed.) Onas, Yaganes, Haush y Alacalufes. 
Vida, costumbres e historia. Buenos Aires: Editorial Dunken.

Cárdenas, R., Montiel, D., y Grace, C. (1993). Los Chonos y los Veliche de Chiloé. Santiago de Chile: Ediciones Olimpo.

Chapman, A. (2002). Breve historia de los Yamanas desde fines del siglo XVI hasta nuestros días. En C. Odone y P. Mason (Eds.), Mundos Fueguinos. 12 miradas sobre selknan, yaganes y kawésqar (pp. 169-190). Santiago de Chile: Taller Experimental Cuerpos Pintados.

Coiazzi, A. (1914). Los Indios del Archipiélago Fueguino. Santiago de Chile: Imprenta Universitaria.

CONADI (2008). (Generalidades etnográficas kawésqar). Otenido de http://es.wikipedia.org/wiki/Alacalufe

Córdoba, A. de (1788). Relación del último viaje al Estrecho de Magallanes de la fragata de S.M. Santa María de la Cabeza. Madrid: Editorial Viuda de Ibarra, hijos y compañía.

Csordas, J. T. (2003) (1994 1a ed.). Introduction: the Body as Representation and Being-in-the-worl. En T. Csordas (Eds.), Embodiment and Experience. The Existential Ground of Culture and Self (pp. 1-20). Cambridge: Cambridge Studies in Medical Anthropology.

Durán, M. A., Heras, D., García, C., Caillavet, F., \& Moyer, M. (1988). De puertas adentro. Madrid: Ministerio de Cultura, Instituto de la Mujer, Serie Estudios.

Elias, N. (1987). El proceso de la civilización. Investigaciones sociogenéticas y psicogenéticas. México: Fondo de Cultura Económica.

Emperaire, J. (1963). Los nómades del mar. Santiago de Chile: Ediciones de la Universidad de Chile.

Entwistle, J. (2002). El Cuerpo y la Moda. Una visión Sociológica. Buenos Aires: Paidós.

Esteban, M. L. (2004). Antropología del cuerpo. Género, itinerarios corporales, identidad y cambio. Barcelona: Ediciones Bellaterra.

Foucault, M. (1984). Vigilar y castigar. Nacimiento de la prisión. México: Siglo XXI.

Godelier, M. (1986). La producción de grandes hombres. Poder y dominación entre los Baruya de Nueva Guinea. Madrid: Akal.

Goffman, E. (1987). La presentación de la persona en la vida cotidiana. Buenos Aires: Amorrortu.

Goiri, R. (1997). La historia de los Kawashkar. Punta Arenas: Ediciones de la Universidad de Magallanes.

Grebe, M. E. (1974). La música alacalufe: aculturación y cambio estilístico. Revista Musical Chilena, XXVIII, 126-127, 80-111.

Gusinde, M. (1951). Hombres primitivos de Tierra del
Fuego. Sevilla: Publicaciones de la Escuela de Estudios Hispano-Americanos de Sevilla.

Gusinde, M. (1989) (1939 $1^{\mathrm{a}}$ ed.). Los Indios de Tierra del Fuego. Tomo IV. Antropología Física. Buenos Aires: CAEA.

Gusinde, M. (1991) (1974 1ª ed.). Los indios de Tierra del Fuego. Tomo III (1 y 2) (Los Halakwulup). Buenos Aires: Centro Argentino de Etnología Americana (CAEA).

Hall, E. (1972). La dimensión oculta. Madrid: Siglo XXI.

Hammerley Dupuy, D. (1952). Los Pueblos Canoeros de Fuegopatagonia y los límites del hábitat Alakaluf. RUNA Archivo para las Ciencias del Hombre, V, 134-170.

Herrera, J., Manquián, D., \& Queduman, D. (2007). Indígenas urbanos de Punta Arenas a través de las asociaciones étnicas "Artesanos del Pueblo Kawashkar" y "PewuAntu" (Tesis de Grado). Punta Arenas: Facultad de Humanidades y Ciencias Sociales, Universidad de Magallanes.

Knapp, M. L. (1985). La comunicación no verbal. El cuerpo y el entorno. Barcelona: Paidós.

Kuzmanich, S. (1980). Cuatro pueblos ... y un destino. Santiago de Chile: Editorial Salesiana.

Lalueza, C., Hernández, M., \& García-Moro, C. (1997). La morfología facial de las poblaciones fueguinas: ¿reflejo de una adaptación al frío?. Anales del Instituto de la Patagonia, 25, 45-58.

Lausic, S. J. (1993). Gentes de la Patagonia. Bandas aborígenes patagónicas y fueguinas: chonos, kaweskar, aonikenk, selk'nam, haus, yámanas. Punta Arenas: Atelí Ltda.

Le Breton, D. (1991). Cuerpo y antropología: sobre la eficacia simbólica. Diógenes, 153, 89-104.

Le Goff, J. (1990). ¿La cabeza o el corazón? El uso político de las metáforas corporales durante la edad media. En M. Feher et al (Eds), Fragmentos para una historia del cuerpo humano (pp. 12-23). Madrid: Taurus.

Manzo, L. (2002). Los pueblos indígenas australes. En G. Flores, A. Palomino, J. Curilen, \& L. Manzo (Eds.), Los pueblos indigenas de Chile. Material de apoyo a la educación intercultural bilingüe (pp. 117-169). Santiago de Chile: Gobierno Regional Metropolitano.

Martinic, M. (2004). Archipiélago Patagónico. La última frontera. Punta Arenas: Ediciones de la Universidad de Magallanes.

Martinic, M. (2006). Historia de la Región Magallánica. Tomo I, II, III y IV. Punta Arenas: Ediciones de la Universidad de Magallanes. 
Mauss, M. (1979) (1936 $1^{\text {a }}$ ed.). Sociología y Antropología. Madrid: Tecnos.

Merleau-Ponty, M. (1966). Signos. Barcelona: Seix Barral.

Odone, C., \& Mason, P. (2002). Culturas tradicionales. Patagonia. 12 Miradas sobre Selknam, Yaganes y Kawesqar. Santiago de Chile: Taller Experimental Cuerpos Pintados.

Orquera, L. A., \& Piana, E. L. (1995). La imagen de los canoeros magallánico-fueguinos: conceptos y tendencias. Runa, XXII, 187-1245.

Peralta, M. V. (1993). Etno-educación en las culturas Yagan y Kawashkar. Una propuesta curricular para su integración en el sistema educativo (tesis de grado).
Santiago de Chile: Facultad de Ciencias Sociales, Universidad de Chile.

Tonko Paterito, J. (2008). Relatos de viaje kawésqar. Onomázein, 18(2), 11-47.

Vega, C. (1995). Cuando el cielo se oscurece (Samán arkachoé). Historia de vida, testimonio alakalufe de Alberto Achacaz Walakial. Punta Arenas: Editorial Atéli.

Vega, C., \& Grendi, P. (2002). Vejámenes inferidos a indígenas de Tierra del Fuego. Tomo III. Punta Arenas: Corporación Nacional Indígena de la XII ${ }^{a}$ Región.

VV.AA. (1976). Expedición a Chile. Vol. III. Santiago de Chile: Editorial Nacional Gabriela Mistral. 
